\title{
The New Neighbor across the Street: An Outlook for Battery Electric Vehicles Adoption in Brazil
}

\author{
Jorge Enrique Velandia Vargas * $\mathbb{C}$, Joaquim E. A. Seabra, Carla K. N. Cavaliero, \\ Arnaldo C. S. Walter, Simone P. Souza and Daniela G. Falco
}

School of mechanical engineering, State University of Campinas, Campinas, São Paulo 13083-860, Brazil; jseabra@fem.unicamp.br (J.E.A.S.); cavaliero@fem.unicamp.br (C.K.N.C.); awalter@fem.unicamp.br (A.C.S.W.); spsouza@unicamp.br (S.P.S.); falco@fem.unicamp.br (D.G.F.)

* Correspondence: jevelandiav@fem.unicamp.br; Tel.: +55-1935213284

Received: 24 July 2020; Accepted: 8 September 2020; Published: 11 September 2020

\begin{abstract}
As the automotive industry steers towards electromobility and electric vehicle adoption surges, Brazil and other Latin-American countries remain laggards. The Brazilian scenario exhibits unique features, such as a powerful automotive sector with large investments in internal combustion engine technology and a well-established biofuels market based on flex-fuel technology. Although energy security, urban air pollution, greenhouse gas emissions mitigation, and technological advantage have been common drivers for the adoption of electric vehicles worldwide, the Brazilian immediate motivations are different, and the biofuels business ecosystem is likely to transform the path for electromobility. High tag price and public charging infrastructure absence have deeply discouraged electric vehicles adoption. A lack of regulation and a national consensus about the role of electric vehicles have been notorious. In fact, only in 2018 did the electricity regulatory agency (ANEEL) issue a resolution permitting the sale of electricity for recharging. The objective of this review was to create an outlook of the Brazilian transportation landscape. We identified relevant players, public charging infrastructure initiatives, market and other barriers, and regulation actions by consulting academic literature, media sources, and reports. We do not claim to predict the evolution of electrification. Instead, we aim to consolidate the information which can be used for decision support or strategy definition among entrepreneurs or policymakers. The main findings here are the necessity of a model for electrification able to create a synergy with biofuels and the urgency of having well-defined policies on what Brazil wants from electromobility.
\end{abstract}

Keywords: Brazil; Battery electric vehicles; biofuels; charging infrastructure; open standards

\section{Introduction}

The last years have witnessed a rapid increase in the sales of battery electric vehicles (BEVs) worldwide. During 2017, global BEV sales surpassed one million units for the first time [1]. This takes place as the urgency of addressing poor air quality and the emission of greenhouse gases (GHG) has invigorated electromobility as an alternative for mitigation of fossil fuels use impacts [2].

In contrast, analysts report that the production peak of internal combustion engine vehicles (ICEV) is likely to be reached in the next years [3]. In Latin America, electromobility is still in the early stages. Several barriers, such as high tag price and non-availability of charging infrastructure, account for the adoption lag. In the region, Chile [4], México, and Colombia [5], have already initiated projects on public electromobility. Recently, São Paulo city (SP) announced an electric bus deployment pilot project [6].

Aiming to promote BEV and hybrid electric vehicles (HEV) adoption in Brazil, some tax breaks have been granted. The states of Ceará, Maranhão, Pernambuco, Sergipe, Piauí and Rio Grande do Sul 
granted an ownership tax exemption on both BEVs and HEVs [7]. Furthermore, resolution 97-2015 issued by the Foreign Chamber of Commerce (Camex), granted an HEV importation tax abatement from $35 \%$ to a maximum rate of $7 \%$ [8,9]. Although financial incentives have proven effective to promote electromobility [10-12], the allocation of scarce public resources, especially in developing countries, is difficult, given that diverse political priorities compete for limited taxpayer funds $[13,14]$.

Besides financial incentives, the city of SP offered exemptions to road access restrictions [15]. Nevertheless, those actions have been insufficient to compensate for the high costs of purchasing BEVs and charging stations, also known as electric vehicle supply equipment (EVSE). Currently, BEVs represent less than $0.1 \%$ of Brazilian fleet [16]. The high tag price of imported cars and EVSE [17] imply that the BEVs in Brazil are niche products [18].

Given the low battery range of many models and the lack of public EVSE, users are concerned of running out of charge far away from any charging point. This is known as range anxiety and acts as a deterrent for adoption. Range anxiety is not usually a concern for vehicle fleets, due to the predictability of vehicle charging and routes [19]. Indeed, most of the currently deployed BEVs in Brazil are employed for government, corporate service, or public transportation. Only a few hundred BEVs are for private use [20].

Any attempt to change the transportation paradigms in Brazil will face a mature market with unique features. Firstly, a powerful automotive sector with numerous investments in ICEV technology. During 2019, Brazil produced 2,803,841 passenger cars, including light commercial vehicles [21]. Reportedly, the country ranked as the world's eighth vehicle producer in 2017 [22] and seventh in 2018 [23], whereas the automotive sector represented about $22 \%$ of the industrial gross domestic product [24]. Likewise, in 2017, Brazil was the second largest producer of sugarcane bioethanol and soybean biodiesel worldwide [25], hence, the energy crops sector is a powerful player. Electromobility arrives slowly; only in June 2018, the National Agency of Electric Energy (ANEEL) issued the resolution $\mathrm{N}^{\circ} 819$ providing a legal framework for the commercial recharging of BEVs [26]. This marked a milestone for this new market since commercial recharging was not allowed in Brazil beforehand.

Furthermore, the Brazilian government has traditionally implemented importation barriers in order to encourage automotive local production and investment [27]. In fact, the implementation of Inovar-Auto program, valid from 2012 to 2017, imposed vehicle importation quotas for car manufacturers, also known as original equipment manufacturers (OEM). In the case of any OEM exceeding the determined importation quota, each imported vehicle had to face extra tariffs. Once those restrictions were gone, the importation of vehicles soared [28]. Concerns are that, in a fewer trade restrictions scenario, some companies would prefer to face importation tariffs and produce the vehicles outside Brazil instead of locally, implying job losses. Actually, the trade restrictions are likely to change. On June 2019, the Mercosur states and the European Union reached an agreement on trade conditions, able to change the importation rules for cars and parts [29]. Adding more complexity to the landscape, the Brazilian automotive fleet displays a large share of flex-fuel vehicles, whose engines can run on both gasoline and ethanol or a mixture of both. The share of flex-fuel vehicles in the national automotive fleet reached about 67\% in 2018 [30], whereas flex-fuel share for new vehicles in 2019 was around $87.4 \%$ [21]. Figure 1 displays the sales evolution of gasoline $C$-composed of $73 \%$ gasoline and $27 \%$ anhydrous ethanol-and hydrated ethanol and the share of vehicles using flex-fuel and only gasoline engines.

Although energy security, urban air pollution, GHG emissions mitigation, and technological advantage justify the international adoption of BEVs, the Brazilian motivations may be different. Energy security is not deemed as an immediate concern considering the discovery of pre-salt oil fields [31] and the biofuels production. This occurred in spite of a truck driver strike which roughly exposed supply chain vulnerabilities [16].

Despite the significant contribution of renewables in the local electricity mix [32], which amplifies GHG emissions mitigation potential of BEVs, [33-38] sugarcane ethanol may be an alternative for $\mathrm{CO}_{2}$ 
emissions mitigation [37,38]. Air quality and technological advantage have proven, so far, insufficient to boost BEV adoption.

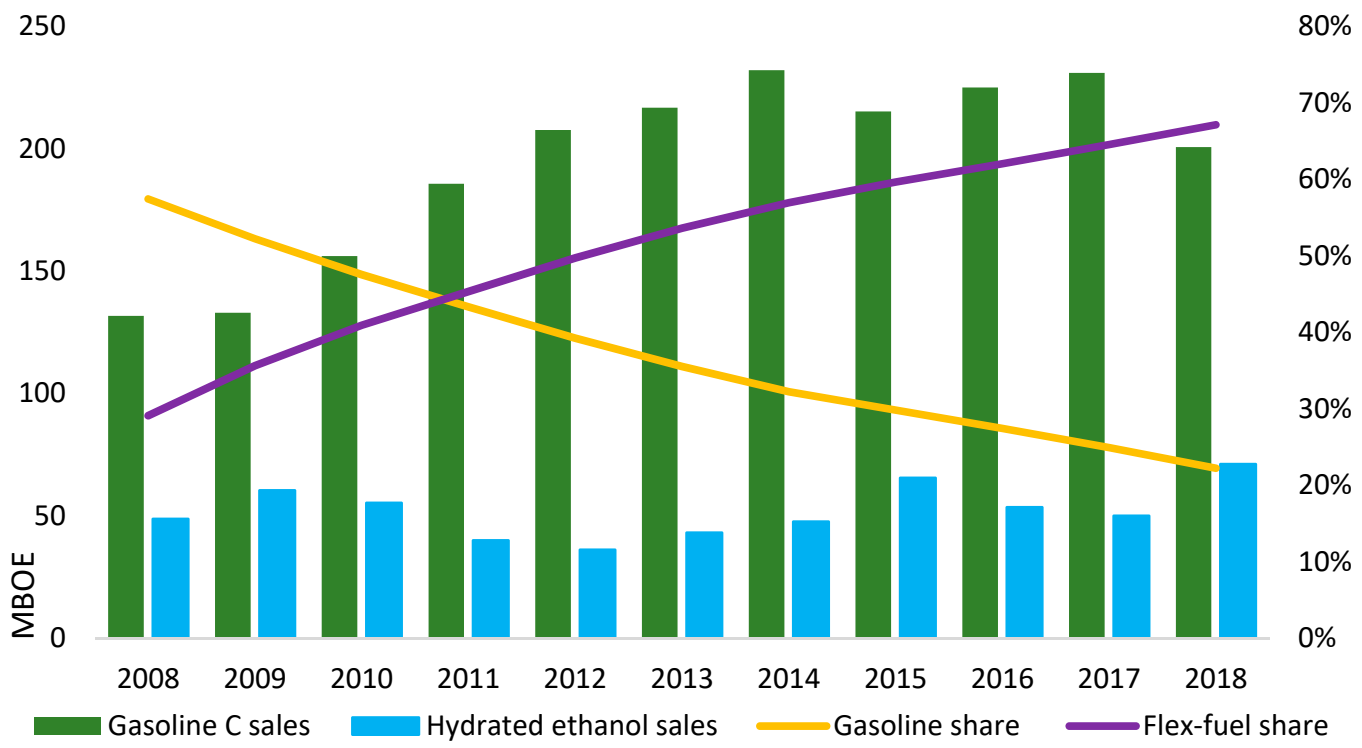

Figure 1. Evolution of sales of hydrated ethanol and gasoline $C$ in Million barrels of oil equivalent (MBOE) in Brazil. Right axis refers to the evolution of the vehicle share per type of powertrain in the Brazilian light vehicle fleet. Gasoline $\mathrm{C}$ refers to the mandatory anhydrous ethanol blending in the gasoline, $27 \%$ in 2019 .

It remains unclear how transport electrification will take place in Brazil given its very specific features. Cano et al. [39] emphasized that the particularities of emerging markets can create new technologic routes or applications. Thus, a li-ion battery-based market should not be taken for granted in the future. Options include nickel-metal hydride, lithium sulfur, lithium air, and zinc air storage devices. Cano et al. [39] also highlighted that, at the sight of a price increase, the Brazilian public is very likely to see a reduced probability of purchasing a BEV.

The objective of this systematic review was to create an outlook of the Brazilian BEV landscape and its particularities. For the construction of BEV market outlook in Brazil we discarded any information older than 2013 for considering it far outdated. For technical aspects, any information previous to 2009 was disregarded. The search was performed in both English and Portuguese, always prioritizing peer-reviewed studies and using ScienceDirect, Scopus, and Google Scholar databases. Non-peer reviewed references were selected for contextualization, aiming to address milestones in BEV adoption, vehicle or EVSE releases, relevant players statements, and other market updates that are not essential for discussion. Figure 2 displays the bibliometric study flowchart. Aiming to keep this review at a reasonable length, some studies which we considered as relevant but not indispensable were discussed only in the SM.

In order to offer a broader insight, the Supplementary Material (SM) includes a brief outlook addressing the expected changes in business models (BM) for BEVs when compared to ICEV BMs and also discusses charging infrastructure deployment. For Brazil, we identified players, regulation actions, and initiatives by consulting academic literature and media sources. We do not claim to predict the evolution of electrification. Instead, we aim to consolidate information which can be used for decision support or strategy definition by policymakers and entrepreneurs.

The paper has been divided into an introduction and two sections, having three sub-sections each. This first section introduced the topic by means of a brief background. Section 2 provides brief overviews on the initiatives, the relevant players, and the regulation in Brazil. Additionally, it presents an introduction on how charging infrastructure would boost a competitive BEV market, and finally 
presents the barriers that electromobility will face in the country. Section 3 displays the discussions about local features, biofuels synergy, or lack thereof, and the electromobility market.

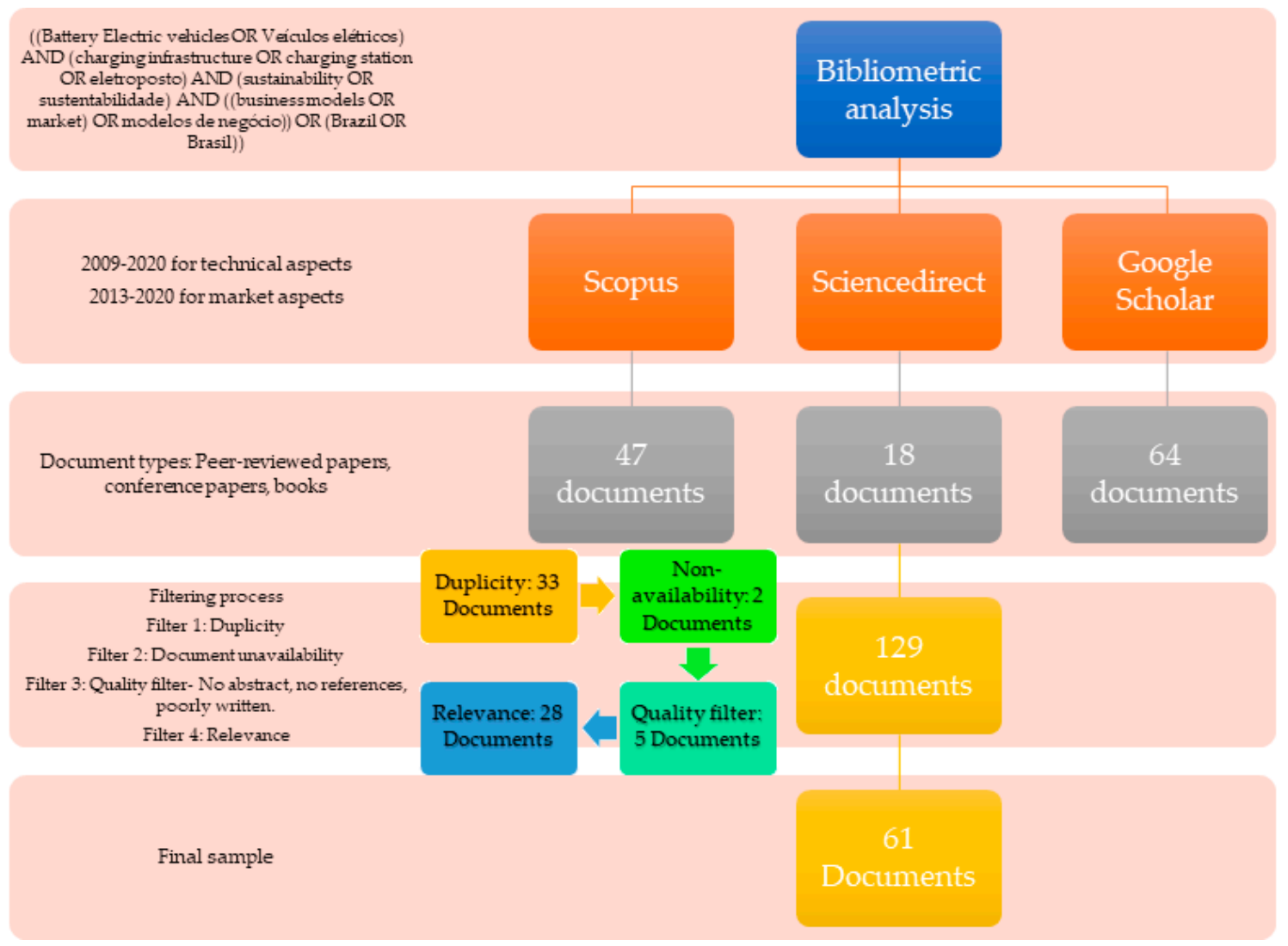

Figure 2. Bibliometric study flowchart.

\section{A Brazilian Tale}

Electromobility entrepreneurships are no novelty in Brazil. During the 1980s, Gurgel S.A. and Furnas Centrais Elétricas S.A jointly developed two electric models without commercial success [40]. The low specific energy of lead-acid and nickel batteries kept BEVs unfeasible until the irruption of Li-ion batteries. Brazilian concerns surrounding energy security promoted biofuels as a solution. The 1970s energy crisis, driven by oil scarcity and soaring prices, led to the creation of the Proalcool program [41] which steered the national energy security policy towards biofuels. Indeed, sugarcane ethanol represents $18 \%$ of total primary energy production and $34 \%$ of energy consumption for light vehicles [42].

Brazil is a follower in terms of BEV technology. Currently, there is no large-scale manufacturing of BEVs. However, there have been initiatives aiming to develop related technology. Initial efforts from small entrepreneurships and research entities on manufacturing were based on ICEVs retrofitting. Moreover, in the lightweight segment, there is evidence of at least three entrepreneurships assembling vehicles locally, namely Gaia, eiON, and Mobilis [43]. Furthermore, Itaipu Binacional carried out a large project based on adaptation of ICEVs $[8,44]$ while private owners created a retrofitting-based association [45]. A comprehensive index of BEV related initiatives and projects, was constructed by Consoni et al. [7] and Fontes [46]. A summary of BEV releases in Brazil is included in the SM.

Retrofitting is useful for entrepreneurs in order to obtain the know-how on chassis and body characteristics. However, evidence indicates that a car architecture based on a BEV design, without ICEV design legacy, results in an increased synergy of powertrain parts, hence requiring fewer modules and reducing weight [47]. In fact, BEV native design allows the OEM to better distribute the battery weight and could augment BEV range while maintaining a price stable. 
A native-electric design could allow OEMs to evolve towards a mass market production scheme just as Tesla did with the Model 3 [48]. Mass production enables OEMs to access mass segments while keeping a sufficient battery capacity to deal with range anxiety. New infrastructures, required for adapting manufacturing plants to BEV native architecture, signify high investments and risks, which not every OEM is willing to face. Some automakers are expected to continue adapting ICEVs into BEVs intended blueprints [49].

Consequently, there is no dominant pathway on BEV design, nevertheless, native design, reportedly, fits well on a design-to-cost approach, satisfying the urgency for a profit in the long term. Whether or not large OEMs decide to invest in BEV production in Brazil could depend on political and macroeconomic factors, given the extent of the investments. For instance, the Mercosur-EU agreement signed at the end of June 2019 eliminates customs duties for cars and parts being imported from EU countries [29], and has been applauded by European OEMs [50].

\subsection{Initiatives, Relevant Players and Regulation}

Electromobility players are all those organizations interested in transport electrification. New regulatory frames and new BMs would have to include stakeholders which were never part of the value chain in the ICEV business, this includes OEMs and EVSE providers, R\&D institutions, financial entities, private associations, and lawmakers.

Fontes [46] constructed a comprehensive index of BEV initiatives in Brazil. Likewise, Barassa [51] and later Consoni et al. [7] built a map of policies, initiatives and players and concluded that, although efforts were made on research, financial and institutional spheres, they were no part of a coordinated structure. Indeed, the Sibratec network (2011-2015) [52] aimed to integrate the efforts of diverse research institutions; nevertheless, it ended without significant impacts.

So far, the initiatives displayed exploratory intentions, aiming to better understand the end-user of electromobility and to track the development of a certain technology. Interestingly, many of the initiatives were not designed for pure BEVs but for HEVs. Table 1 displays a sample of the most divulged electromobility projects in Brazil. EMOTIVE and VAMO projects have been a source of data for diverse studies [53-58]. In fact, recent research emphasized that phasing out ICEVs jointly with VAMO project deployment results in an overall reduction of GHG emissions and a net increase in BEV adoption [58]. These studies are described more in detail in the SM.

Table 1. Sample of the most divulged electromobility projects in Brazil.

\begin{tabular}{cccc}
\hline Manager & Location & Period & Features \\
\hline CPFL & Campinas (SP) & 2013-2018 & $\begin{array}{c}\text { Electromobility large-scale laboratory in Campinas } \\
\text { metropolitan area. BEV leasing to local companies } \\
\text { to be used in their fleets. Included EVSE } \\
\text { installation. CPFL is a local DSO }\end{array}$ \\
\hline Light & Rio de Janeiro (RJ) & 2013-2015 & $\begin{array}{c}\text { Deployed BEVs within Rio de Janeiro Federal } \\
\text { University campus, in order to study distributed } \\
\text { generation, smart measurement of energy, BEV use, } \\
\text { and power storage. }\end{array}$ \\
\hline CELPE & $\begin{array}{c}\text { Fernando de } \\
\text { Noronha (PE) }\end{array}$ & 2016- & $\begin{array}{c}\text { Basic smart grid deployment based on } \\
\text { photovoltaic generation. }\end{array}$ \\
\hline VAMO & Fortaleza (CE) & 2016- & $\begin{array}{c}\text { Applet- based BEV carsharing. First of its kind } \\
\text { in Latin-America. }\end{array}$ \\
\hline Carroleve & Recife (PE) & 2015-2018 & Applet- based BEV carsharing. \\
\hline
\end{tabular}

Concerns about energy security and technological development have steered Brazilian regulation in the past. Furthermore, several regulatory actions addressing environmental and economic concerns have been issued; however, electromobility was barely mentioned despite being wide scope actions. 
Three programs deserve special attention: Proconve, Rota 2030, and Renovabio. Proconve focused on air pollutants emission and noise control, while Renovabio endeavors to promote the proper expansion of biofuels in the energy matrix, and Rota 2030 looks forward to expanding the global insertion of the Brazilian automotive industry into the global market. More details on policies and federal funding institutions is found in the SM.

Rota 2030 offers tax slashes to OEMs investing in R\&D of auto parts not being manufactured in Brazil [59] and is expected to guide OEM efforts to approach the local market in the next years [60]. Criticism arose due to incentives not being as robust as expected, as they hinge exclusively on energy efficiency and vehicle weight $[61,62]$. Furthermore, Rota 2030 does not include a specific policy for BEVs, but only for ethanol fueled HEVs. This is in concordance with the National Center of Research on Energy and Materials (CNPEM) predictions of fossil fuels in Brazil being replaced by a combination of ethanol and electromobility. CNPEM even perceives a potentiality to export this model, emboldened by the fact that India, China, the US, and other countries in Latin America have incorporated ethanol to gasoline [31].

Clear policies regulating the electricity sector and its relationship with electromobility are fundamental. ANEEL resolution $\mathrm{N}^{\circ}$ 819-2008 was intended to create a safe framework for entrepreneurs investing in public EVSEs [13]. An additional motivation was the issuing of bills PL 4751/2012, PLS 780/2015 [63], and PLS 454/2017 [64], submitted to congress, which could render the installation of public EVSE compulsory and even ban the sale of ICEVs in 2060 analogously to other countries [65]. Furthermore, in November 2018 ANEEL announced a call for proposals for the strategic project 22/2018, "Development of Solutions in Efficient Electrical Mobility". The goal is to encourage the deployment of technologies for electromobility which include new BMs, devices, services and infrastructures, [66]. More information about ANEEL role and motivations is found in the SM.

Despite the absence of an electromobility policy in Rota 2030, local authorities have begun to recognize the necessity of including biofuels and electromobility in the 2050 national energy plan (PNE2050) [67]. Additionally, it is preparing to issue a national plan for electromobility [68]. The Energy Research Enterprise (EPE), a public research company, recommended the establishment of a realistic roadmap for electrification and measurements to avoid technological lock-in [69].

\subsection{Charging Infrastructure Development}

Investors in charging infrastructure have a keen interest in determining the adequate number of stations and the most suitable locations for them, given a certain fleet size. Always aiming to minimize initial investments [70], an effective placing must maximize occupation time and guarantee ease of accessibility.

The NREL EVI-Pro model was crafted to determine the best areas for EVSE installation intending to support BEV adoption based on travel and traffic patterns [71]. Although fast charging demand is anticipated to stay low for some time, a minimum number of units is necessary for users to cope with range anxiety. Early EVSE installation should prioritize densely visited areas, e.g., malls, hospitals and supermarket parking areas. EVSE installation for BEV-based fleets would be simpler as their routes are defined in advanced. In contrast, private users are more difficult to predict [19].

Similar research can be found in Brazil. EVSE installation in the Federal University of Rio de Janeiro campus was proposed by Calçado [72]. Likewise, Peres [73] proposed it for the city southern districts, concluding that the best areas are those presenting the largest chances of high occupation time and accessibility. Another study, oriented to determine the better locations for EVSE placement [74], resulted in a map showing that areas for slow charging are those exhibiting higher incomes and high population density. Better areas for semi-fast charging are the districts presenting important concentration of commercial establishments, e.g., shopping malls and public transport stations. The proximity to highways and access roads are the most important attributes for the installation of fast chargers. A similar methodology, this time for Belo Horizonte (BH), obtained similar results [75]. Recently, a more complex model was tailored for São Paulo city. It includes the number of daily trips made by 
transportation mode and some points of interest, e.g., gas stations, private and public parking spaces, universities and colleges, and markets and malls. A higher complexity model is able to deal with a larger amount of georeferenced information and may produce more precise outputs for charging demand and location. The model, however, was not able to capture crime-related concerns.

The higher income districts of BH and RJ gathered most of the suggestions for EVSE installation. In the case of private electromobility being promoted by public funding, this might imply that much needed public resources required to enhance public transportation are used for private benefit. Although not developed for Brazil, research has found that early BEV adopters are usually male, present high incomes, and own more than one car, as expected from a niche product [76]. Both studies $[74,75]$ emphasized that security issues could hamper the installation of public EVSE in Brazil. The authors emphasize the need for synergy between authorities and investors in order to promote a BM capable of attracting investments for EVSE installation.

During July 2018, the first fast charging station placed on a highway was inaugurated in São Paulo-Rio de Janeiro road [77] by concessionaire Energias de Portugal (EDP). Simultaneously, EDP announced investments in electromobility startups in partnership with BMW [78]. The charging service remains free until a BM is structured. Later, on December 2018, the Energy Company of Paraná (Copel) inaugurated the largest set of EVSE on a road in Brazil, covering a route of $700+\mathrm{km}$, linking the Port of Paranaguá to the Iguaçu Falls. All of the 11 charging stations are already in operation [79]. Charging is free also, however, registration is required [80]. Although both initiatives are important, from an overall perspective, public EVSE in Brazil remains scarce, and only about 100 charging stations had been installed up to 2018, which renders long trips impossible on most of the national roads [8].

The EVSEs in both highways include all the commercially available plugs in the market, granting accessibility. In the future, the absence of a unified standard would hinder the installation of public and residential EVSEs [7]. So far, standards for physical plugs have mostly been accepted. Nevertheless, the communications and payment standards have been less standardized. At some point, it would become necessary for Brazil to regulate public charging standards as has happened abroad. For instance, aiming to ensure that BEV users can charge anywhere, the Netherlands regulates every EVSE in the country, demanding all operators to adopt common standards [81].

The National Bank for Economic and Social Development (BNDES) granted R 6.7 million in funds for a EVSE development project which will be implemented by the Brazilian Company of Research and Industrial Innovation (Embrapii) and the Research and Development Center in Telecommunications (CPqD) [82,83]. The objective is to develop the first Brazilian EVSE. Resources will originate from Funtec, a fund focused on applied research and innovation projects. Up to now, only ABB [84], BYD [85], and Volvo [86] offer EVSE in Brazil.

Sooner or later, free charging will cease. BMs will vary depending on whether the EVSE is private or public. The simplest scheme for BEV charging is at private residences. Here, only the car and the EVSE are required. However, if users want to benefit from a more flexible charging process, e.g., different hour rates, more elements will be necessary. For further EVSE functionalities, the so-called charging point operator (CPO) appears. The CPO is responsible for remotely operating the EVSE. Communication between the CPO and the EVSE have already been standardized by the open charge point protocol (OCPP) [87-89].

Public charging requires a complex structure. Each owner requires an ID for identification and billing purposes. The entity providing communications for this ID is known as the E-mobility service provider (EMSP). During public charging, the CPOs must communicate with the EMSP for data transmission. This scheme is analogous to mobile phone roaming, where a user can communicate through different transmission towers. Aiming to avoid too many communication channels between different parties, a central hub for data verification, known as the clearing house, plays its role [90]. The clearing house can be substituted by a peer-to-peer verification scheme. Several different communication protocols for roaming have been developed in Europe, namely OCPI, OCHP, OICP, and eMIP [87]. None of them is dominant but at least one of them is likely to be adopted in Brazil. 
The public charging process can be summarized as follows: the BEV user validates their ID at a public EVSE. The CPO, which remotely controls the EVSE, requests the EMSP for authorization. Once the EMSP has approved the request, the charging process begins. Throughout the charge, the EVSE measures the energy sold and even the parking time if required. Finishing the process, these data are sent back to the EMSP again, including the CPO's fee for using the EVSE. Figure 3 illustrates a simplified version of the BEV charging landscape, including private and public charging, and a potential smart charging scenario. We also identified the most common protocols for communication between the parts. This study deemed smart grid and vehicle to grid technologies as unfeasible in Brazil for at least the next decade. Thus, it will not be further elaborated here, but a brief review is found in the SM.

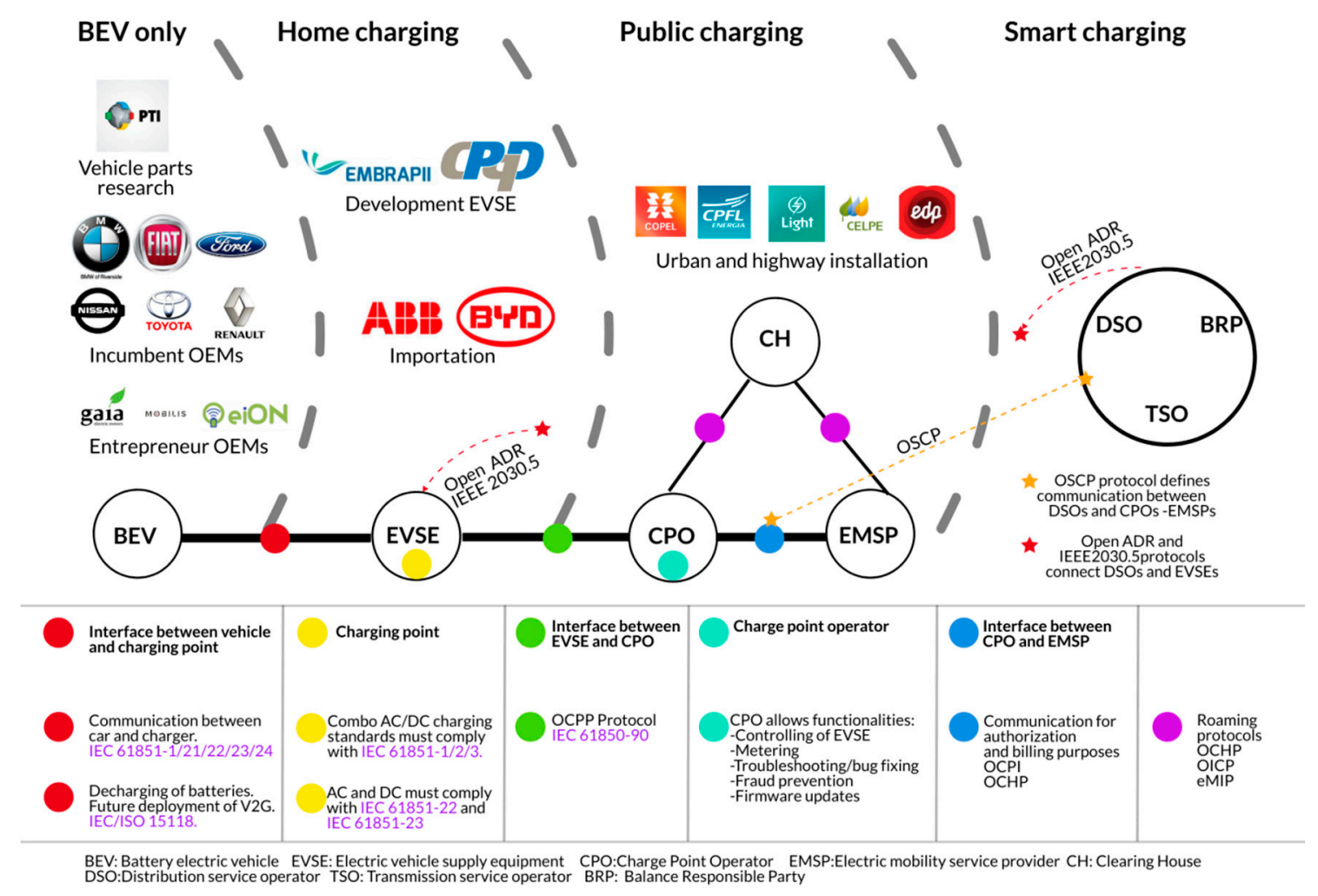

Figure 3. Diagram of relevant players and communication protocols for transport electrification and commercial charging in Brazil. From left to right: Vehicle only, home charging, public charging and a scenario for smart charging.

This complexity could affect data transmission; standardization is crucial for this emerging infrastructure. The participation of the Brazilian Technical Standards Association (ABNT), in charge of issuing the Brazilian technical standards (NBRs), will be decisive. Brazil, acting as a follower on terms of BEV technology, usually adapts either ISO or IEC international standards for local needs. Through its Brazilian Committees, ABNT has already ratified a number of standards, related mostly to battery recharge, sockets, conductive recharge and other hardware systems. A comprehensive list of adapted international standards is available at Consoni et al. [7].

This review assumed battery swapping technology as not being feasible in Brazil in the short term, due to lack of standardization and current inaccuracies in battery state of health $(\mathrm{SOH})$ and state of charge (SOC) estimation. Additionally, among BEV owners battery swapping is not the preferred option. According to Li [14], Tesla's trials revealed that battery swapping stations are not popular among their customers who prefer supercharging stations. Likewise, this review does not consider the deployment of wireless charging in Brazil in the next decade, despite technical advances, including the release of SAE J2954 standard, which addresses safety concerns, interoperability, and performance. 


\subsection{The Barriers of a Challenging Market}

In an effort to identify the main barriers electromobility would face in the BRICS (Brazil, Russia, India, China and South Africa) and the strategies used by OEMs to face them, Pratiwi [91] interviewed Renault Brazil executives to gather perspectives from inside the firm.

Renault started a pilot project in BEV deployment, based on lending BEVs to selected customers, expecting them to gain experience and provide feedback. Renault cooperated with fleet owners, aiming to develop working standards for charging connectivity, EVSE installation, and financing. Due to BEV high initial investment, their long-term benefits are often disregarded by potential customers. Thus, Renault's strategy included corporate education.

The executives were requested to enumerate the five most important barriers for BEV adoption in Brazil and the strategies Renault is working on to counteract them. Results are displayed in Table 2.

Table 2. Top ranked barriers to adoption and strategies to overcome them in Brazil, according to Renault executives.

\begin{tabular}{|c|c|c|}
\hline Rank & Barrier & Description \\
\hline 1 & Financial & BEV high tag prices. \\
\hline 2 & Macro-economic & $\begin{array}{l}\text { Brazil has faced GDP decrease, rise in unemployment rate and } \\
\text { low growth rate in the last years. [92] }\end{array}$ \\
\hline 3 & Infrastructure & Lack of public EVSE. \\
\hline 4 & Institutional & $\begin{array}{l}\text { Any support from the government is missing. Absence of } \\
\text { EVSE and BEV adoption in urban areas. }\end{array}$ \\
\hline 5 & Demand & $\begin{array}{l}\text { Practically inexistent market. Customers do not have sufficient } \\
\text { knowledge about electric vehicles. }\end{array}$ \\
\hline Rank & Strategy & Description \\
\hline 1 & Demo and develop niche & BEV loans and development of effective strategies. \\
\hline 2 & Pilot project & BEV lending to selected customers for they to gain experience \\
\hline 3 & Lobbying & $\begin{array}{l}\text { Lobbying is intended to face institutional, infrastructure and } \\
\text { financial barriers. Cooperation with suppliers and federal and } \\
\text { state organs to promote discussion on public EVSE. }\end{array}$ \\
\hline 4 & Financial aid & $\begin{array}{l}\text { Renault offers cooperation with customers who can opt for } \\
\text { leverage options, including leasing. }\end{array}$ \\
\hline 5 & Knowledge development & $\begin{array}{c}\text { Besides R\&D, awareness events are carried out for } \\
\text { educational purposes. }\end{array}$ \\
\hline
\end{tabular}

Other factors hamper BEV adoption. Besides range anxiety, owning a BEV could create resale anxiety, which reflects how afraid potential BEV owners are of facing low resale prices in the secondhand market [93]. Moreover, for public electromobility, Bermudez [94] concluded that (i) the high initial cost of electric busses compared to conventional ones, (ii) lack of financial incentives for low-emission fleets, iii) resistance of fleet operators and diesel bus companies to new technology, (iv) technological uncertainties related to the autonomy of the battery and the charging network, and (v) the absence of a special electricity tariff for public transport are the main barriers in Brazil.

Finally, BEV manufacturing by Renault-and by other OEMs too-is still low. This leads to over-demand for some models, resulting in long delivery times. In the future, the different plugs for EVSE available in the market may also become a barrier as several options will be available [7,95], analogous to VHS and Betamax competition in the 1990s. 


\section{Discussion and Final Remarks}

\subsection{Prices, Biofuels Competition and Lack of Consensus, Overwhelming Challenges}

High tag prices, accessible only for a few, worsened by poor macroeconomic indicators, denoting a population with stagnated or decreased revenues, were identified as preponderant hurdles for BEV adoption [91]. As part of the EMOTIVE project, the total cost of ownership (TCO) of BEVs and ICEVs employed by three local companies in their fleets was documented, all of it based on real usage data [96,97]. The main findings indicate that, for 2015 conditions, Renault Zoe and Renault Kangoo models are economically at a disadvantage compared to Honda Fit and Kangoo Express-flex. This is a consequence of a heavier purchasing tax burden outweighing any advantage provided by BEVs lower usage and maintenance costs, even in a five-year timespan. Furthermore, a prospective scenario was created, seeking to picture a future situation, in which purchase taxes were abated by $50 \%$, annual taxes were reduced from $3 \%$ to $1 \%$ of the total of the car, costs of battery storage reached $150 \mathrm{USD} \mathrm{kWh}^{-1}$ and manufacturing process costs decreased by 50\%. To the present day, annual tax was already reduced in that proportion [98]. Battery storage cost, on average, reached 176 USD in 2018, which strongly suggest that the forecasting could be reached even before 2020. In fact, Tesla claims to have already reached the $150 \mathrm{USD} \mathrm{kWh}^{-1}$ threshold [99]. Additionally, the importation tax was reduced from $35 \%$ to $7 \%$ [8,9], however, it still does not imply a 50\% purchase tax reduction. Finally, considering Lutsey \& Nicholas [100] forecasts, we believe that, despite being on a steady fall, the decrease in manufacturing costs is not likely to have reached 50\% from the 2015 baseline. Thus, the prospective scenario is a fair approximation for the actual TCO of BEVs in the years to come. There were no variations for ICEVs in the prospect scenario. A comparison of both scenarios is given in Figure 4.

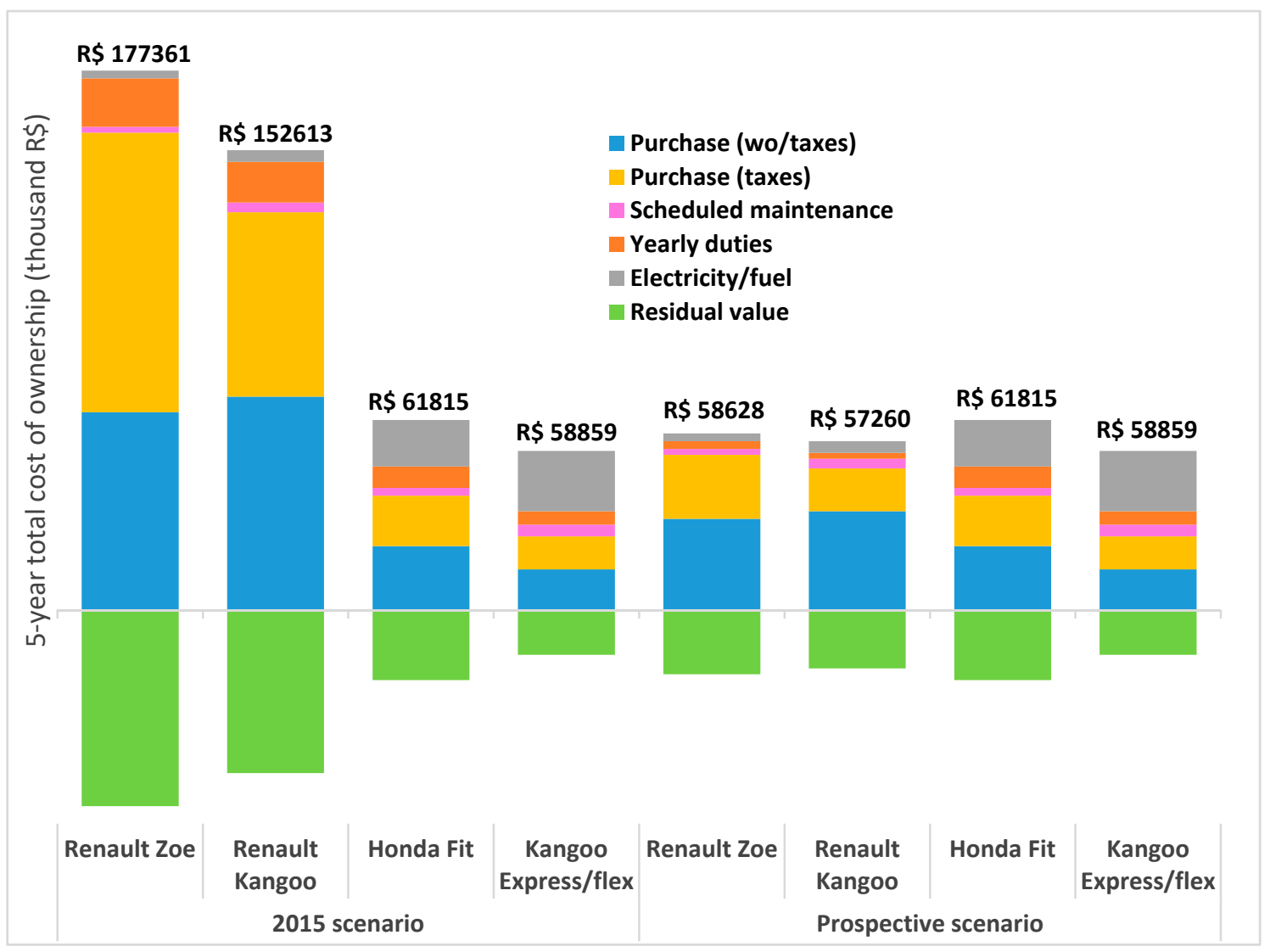

Figure 4. Total cost of ownership for two models of BEVs and ICEVs in Brazilian fleets for 2015 and prospected scenarios based on Marques et al. [96,97]. 
Besides tag price and EVSE availability, other factors could influence BEVs adoption. Research analyzing adoption in the U.S. concluded that electricity prices and financial incentives are relevant factors for users to choose BEVs over ICEVs [101]. We assumed those findings can also be relevant in Brazil since both factors affect the vehicle TCO.

Firstly, electricity prices in Brazil vary depending on generation conditions [102]. Drought is injurious for hydroelectricity [103] and it implies larger dispatches of gas-fueled power plants. Analogously, gasoline rates can vary depending on international oil prices, while taxes add up for the overall price [104]. Secondly, implementation of incentives is unlikely; Brazil just overcame a recession [92], resulting in a government prone to cut public spending. Thus, incentives would hardly be implemented at the federal level $[13,14]$. However, financial support for BEV promotion and public EVSE installation may appear at the state level.

Moreover, it is uncertain whether the potential benefits of electrification for GHG emissions mitigation will be a priority for an administration which has displayed contradictory signals. For instance, it adopted a stance of skepticism on the anthropogenic causes of global warming [105] whilst, on the other hand, it decided to maintain Renovabio program, which strives to promote efficient biofuel production, aiming in part to mitigate lifecycle GHG emissions [106]. In fact, Renovabio came into force in December 2019 and its platform has been working since January 2020 [107]. Furthermore, despite the nationally determined contribution from Brazil, the heart of the COP21 agreement, is still valid by law [108], the entity in charge of implementing the law has been dismantled [109,110].

Besides the lack of incentives and the market barriers, the competition with biofuels may be an obstacle for BEV adoption [20,111]. Voices within the sugarcane sector oppose tax reductions for BEVs arguing it contradicts the objectives of Renovabio policy [106]. In contrast, other voices in the sector acknowledge the inevitability of electromobility and call for this technology to be seen not as a substitute, but rather a complement for biofuels [6,8,31,112]. Baran \& Legey [111] projected that, given a PHEV adoption of nearly $40 \%$ of the total fleet, the demand for liquid fuels would remain almost stable from 2020 onwards. Even for such an optimistic scenario for electrification, biofuels consumption would not decrease.

CNPEM argues that if electromobility relies on imported technology it may jeopardize priority aspects, such as job creation and bioenergy technology leadership, not to mention the balance of payments. Therefore, transport electrification must recognize the Brazilian singularities and adapt to them. Thus, electromobility should not hamper job creation or biofuels leadership. Moreover, it must contribute to prevent dependence on foreign inputs or technologies. The coexistence of electrification and biofuels ought to grant transport reliability and energy security $[13,31]$ and is likely to boost HEVs adoption $[8,16,31]$. Nevertheless, technology forecasting is plagued with uncertainties. In the U.S.A., the sales of HEVs, including PHEVs (plug-in hybrid electric vehicles), have been steadily falling as battery capacity enhanced the BEV range [113]. In fact, General Motors discontinued the manufacture of the famous Chevrolet Volt [114].

In spite of the quick pace of Li-ion battery improvement, the potential of ICEV technology to remain competitive must not be underestimated [115], especially in emerging markets where transport electrification could take decades to arrive and technological routes, other than BEVs, may thrive [39]. For instance, Mazda Skyactiv-X engine technology, whose core is the Spark Controlled Compression Ignition engine. Skyactiv-X merges the best of Diesel (fuel economy, good response at low rpm) and Otto (low emissions, power generation) cycles and is able to be embedded within a "mild" hybrid powertrain [116], and also could be adapted to work on an ethanol-based cycle. Other technological routes are being explored. On April 2019, the State University of Campinas (Unicamp) and Japanese OEM Nissan signed an agreement to study bioethanol as an option to provide energy for a solid oxide fuel cell (SOFC) [117]. Nissan is the first OEM to develop a prototype vehicle exploring this route. Another Asian automaker, BYD, announced the opening of the first Li-ion batteries manufacturing plant in Brazil [118]. In the future the company intends to expand its operations to also manufacture batteries for electric busses. 
Understanding Brazilian particularities is crucial for implementing mobility policies. Electrification will likely arrive in the heavy-duty segment first. One example is the implementation of Law 16802 in SP city. Its ambitious goals, for a 20 years period, require drastic reductions of particulates, $\mathrm{NOx}$ and fossil $\mathrm{CO}_{2}$ emissions when compared to a baseline scenario, which displays a bus fleet based on Proconve 5 and 7 emission standards, equivalent to Euro III and Euro V respectively. Dallmann [119] analyzed the economic and tailpipe emission consequences of the substitution of that diesel-based fleet for BEBs, hybrid busses, Euro VI diesel busses with different blendings of soybean biodiesel and, Euro VI compressed natural gas and biomethane fueled busses. Slowik et al. [81] further refined this analysis by including fuel cell busses. The results for a 10-year timespan-or 70,930 km—show that, despite the higher tag price, the BEBs are the best option from a TCO perspective with all other options staying within a $10 \%$ range of the Proconve 5 baseline bus, except for the fuel cell bus, see Figure 5 . These results are in consonance with O'Donovan et al. [120] who state that $350 \mathrm{kWh}$ BEB TCO is lower than Diesel busses for distances over 80,000 km per year.

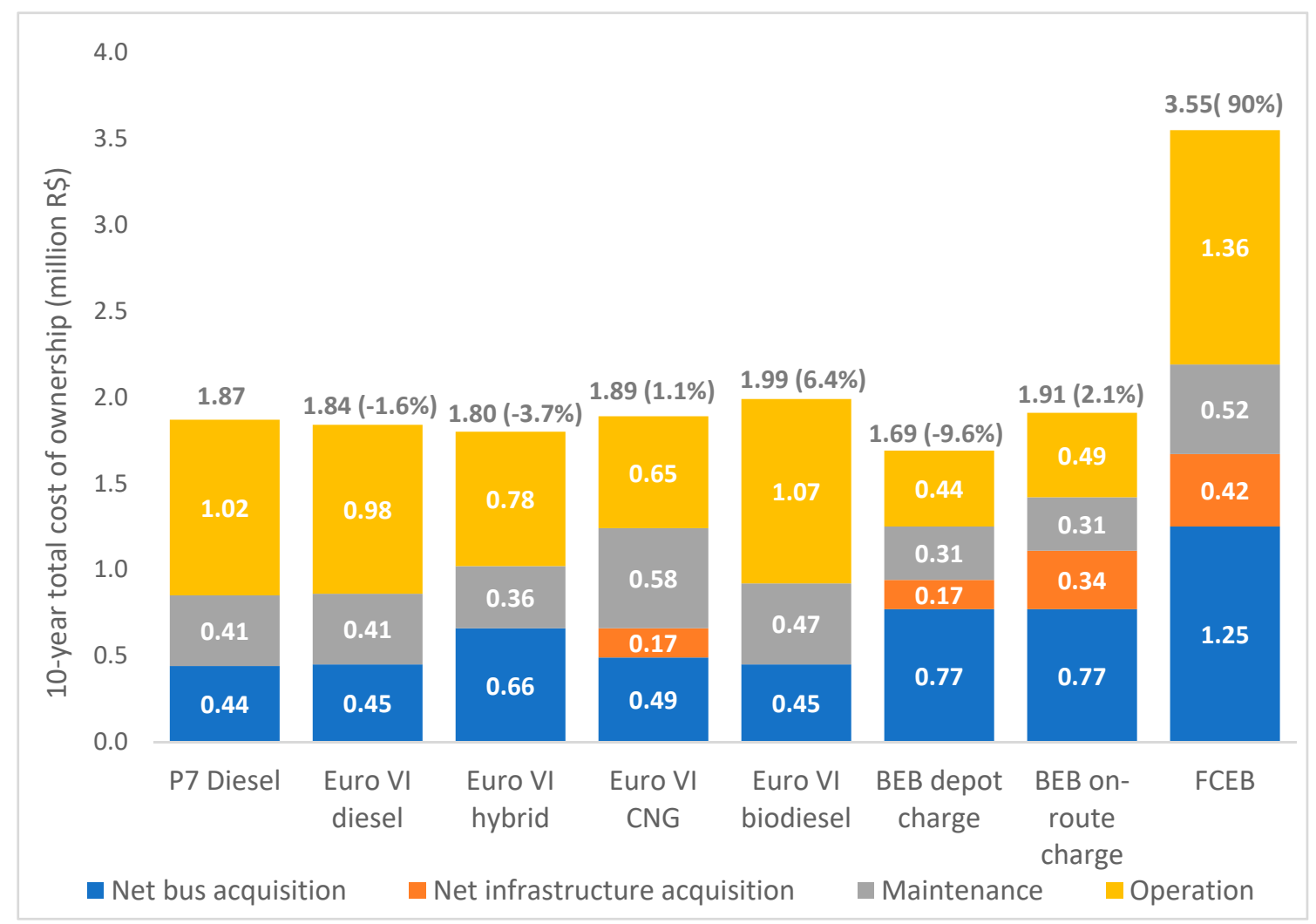

Figure 5. TCO estimates over 10 years for various technologies. Adapted from Dallmann [119] and Slowik [81].

From a $\mathrm{CO}_{2}$ emissions viewpoint, special attention should be paid to Euro VI soybean-based biodiesel option, where indirect land use change considerations might render total life cycle emissions even greater than those in a Proconve 5 Diesel (B15) Bus. Those concerns are found in other studies also. Glensor \& Muñoz [121] found that direct land use change (LUC) is a major contributor to the overall $\mathrm{CO}_{2}$ emissions for car and bus fleets with predominant use of biofuels. Nevertheless, depending on the growing characteristics, biofuels production could result in net carbon sequestration. Moreover, the land carbon content for different Brazilian biomes make the results very sensitive to whether LUC emissions are included or how they are calculated. Dallmann [119] concluded that, whether the high tag price of BEBs does not allow the purchase of BEBs due to funding scarcity, a gradual substitution for Euro VI diesel busses could also be an option to fulfill Law 16802 requirements regarding particulates and NOx emissions. 
Moreover, Consoni et al. [7] identified the absence of a national consensus on electrification as another cause for the low Brazilian BEV adoption. Multiple initiatives for promotion have been created in regulation, industry and research spheres; however, there is no articulation between them. The Brazilian association of BEVs (ABVE) chairperson stresses the absence of public policy as one of the main hurdles for broader adoption [8]. A solid policy could indeed be the basis for BEV adoption. In the past, the implementation of Proalcool program demonstrated the potential of public policies to transform the energy model in the country. Interestingly, to a large extent, the efforts allocated to the electromobility sector are justified by the R\&D investment requirements of law 9991/2000 [7].

\subsection{Electromobility Market and Charging Infrastructure Development}

The creation of a BM for public EVSE is a sine qua non condition for transport electrification [122]. A question remains for the appropriateness of EVSE promotion based on public funding given the tiny current BEV fleet. Estimations from CPFL predict EVSE requirements for up to 80,000 units in 2030 [123], resulting in the typical chicken and egg dilemma [124] for Brazil. ABVE endorsed a self-guided market, implying gradual EVSE installation [8]. Thus, the role of the public sector is fundamental for structuring the first steps on EVSE networks and initiating a virtuous cycle of investments in the area [122].

Gradually, electromobility BMs are expected to incorporate more revenues from data management. Posteriorly, BEVs are expected to resemble computers on wheels, creating other ways of added value to the customer. Revenue schemes focused on EVSE, vehicle data management and location are expected to generate new business opportunities. Additionally, as electromobility is integrated into other transportation modes, an intermodal mobility provider would need to incorporate data from other providers into a single platform for the billing work, so it could be classified as an EMSP [19]. Another sector bound to rapid transformations is the after-sales. This segment is exposed to revenue decrease as a consequence of BEVs having fewer moving parts and, therefore, less complex services and longer maintenance intervals [125].

Despite the challenges, the short term is not entirely discouraging for electrification. Although representing completely different markets, in the U.S.A, cost parity for BEVs and ICEVs is expected in 2025 [49]. In Brazil, Consoni et al. [7] perceived success potential for two main entrepreneurship groups: fleets operation and management of EVSE network. In fact, BEVs are already a competitive choice for fleet operators and cab drivers in the country [13]. Moreover, there is growth potential in the ultralight segment, e.g., scooters, rickshaws, etc.

Competitiveness of OEMs, regarding on-board data management systems, represents a hurdle for the deployment of architectures connecting BEVs, EVSEs, and DSOs. OEMs deem their data as a competitive advantage. Each player prioritizes their own interests, resulting in relationships that have remained notoriously uncooperative. Weiller and Neely [126] conclude that BEV communication systems, traditionally owned by OEMs, should be open for DSOs and CPOs if competition is going to be boosted. Convincing OEMs of the advantages of having a standardized system and open systems is tough. Nevertheless, Tesla already set a precedent in making information open for the sake of competition [127].

Although scarce, Brazil has developed BEV technology. CPqD experience includes characterization of batteries, development of packaging and cooling systems, and development of battery management systems (BMS) [128]. The BMS is the device in charge of controlling different battery parameters: (i) current, (ii) voltage, (iii) $\mathrm{SOC}$, (iv) $\mathrm{SOH}$, and (v) temperature. $\mathrm{CPqD}$ research even includes algorithms for the assessment of SoC [129] and SoH [130].

Denying investments to local BEV technology development would denote relinquishing the chances of developing an industry in the future, restricting the country to peripheral developments $[7,131]$ and squandering the potential for insertion in the global battery supply chain. Although requiring large investments and regional cooperation, Jussani et al. [132] highlighted the Brazilian potential for insertion in the global battery supply chain recognizing the large lithium reserves in neighboring 
countries and the Brazilian expertise in mining. As long as BEV tag prices are significantly higher than ICEV ones, massive adoption will remain unfeasible. Prices depend strongly on battery costs and how successful are OEMs to implement mass production-oriented design. Prices could plunge once the BEVs are manufactured locally but it remains unlikely in the short and medium term considering the high investments required.

Regarding public EVSEs, the prioritization of actions should include the search for consensus on standardization of AC and DC recharging plugs; combo CCS type 1 and 2 would be interesting options since both support AC and DC charging. Equally important, is standardization in EVSE communication protocols. OCPP would be a good candidate, considering it is the de-facto network protocol throughout Europe and is used in nearly 80 countries [89].

In the long run, as a consequence of BEV adoption, the amount of used batteries will soar, meaning that either a second-life or a recycling scheme will be necessary. Up to now, the industrial recycling of Li-ion batteries is able to recover only the most profitable $\mathrm{Co}, \mathrm{Ni}, \mathrm{Fe}, \mathrm{Cu}$, and $\mathrm{Ni}$ in a cost-effective scheme. Currently, lithium from batteries is only recoverable via hydrometallurgic process, but it is not financially feasible. Some hassles are the low price of primary lithium and its low concentration in the battery. A decisive hint to promote battery recycling would be to make compulsory the reuse of materials established by policy [133]. Nevertheless, such policy could crash against the swinging prices of raw metals. For instance, in 2019, prices of lithium and cobalt, two key commodities for battery manufacturing, plummeted due to low demand in China and overproduction [134-137]. Low extraction prices render recycling unfeasible.

\subsection{Final Remarks}

Despite ANEEL's verdict, Brazilian policy seems likely to stay on bioenergy track in the years to come. Renovabio policy is expected to modify the energy outlook in Brazil as Prooalcool did decades ago. By acknowledging the potential of biofuels to reduce GHG emissions, the initiative generates market instruments to compensate producers for increasing efficiency and avoiding emissions [138], thus, awarding good industrial and agricultural practices and providing supply predictability due to the gradual increase of biofuels share in the energy matrix [139].

Electrification does not appear to have the same impetus as in other countries since Brazil does not face the severe challenges in energy security or extreme air pollution as other countries do. BEVs offer significant GHG emissions mitigation, compared to gasoline-driven cars, as a consequence of a predominantly renewable generation mix. However, sugarcane ethanol is competitive in this regard also. Studies comparing BEVs and ICEVS, with a similar power-to-weight ratio, and including the entire vehicles life cycle, determined that the global warming burden of driving one $\mathrm{km}$ in a sugarcane ethanol-fueled car is lower than that of driving one $\mathrm{km}$ in a $\mathrm{BEV}$, assuming the crop land is not a product of deforestation $[37,38]$. In contrast, urban pollution mitigation is an undisputed trump card for electrification. In fact, new regulations will tighten up emission limits for ethanol [140].

Public policy is fundamental to articulate efforts and establish clear rules. Without a clear statement of what Brazil wants from BEVs it will not be possible to compose a set of coherent institutional actions. The particularities of Brazil seem to suggest that a realistic electromobility roadmap should prioritize synergistic solutions, starting with public transportation and including intermodal integration, private fleets and the ultralight segment. Moreover, promoting R\&D for technologies focused on local particularities might boost own technologies, e.g., ethanol-hybridization and ethanol-based fuel cells. Additionally, it is fundamental to balance the pace of entry of new technologies, avoiding the destruction of taxation and understanding the large economic and political risks of negatively impacting biofuels sector.

A successful public charging model will require synergy between two large industries, mobility and energy. Open standards are ideal for promoting a competitive business ecosystem. Firstly, since nobody owns them, anybody with fresh ideas can join in stimulating entrepreneurs. Secondly, open standards avoid technological lock-in by making equipment, such as EVSE, interchangeable, in contrast 
to market leaders who usually try to use their position to impulse their own products. Open standards are not supposed to define any BM. Instead, standards should enable fluid communication between all parties involved.

Environmental highlights in a nutshell: BEVs deployment in Brazil can be an effective way to drastically improve urban air quality while reducing dependence on fossil fuels $[37,38,119,121,141]$. Likewise, electrification is an option to mitigate GHG emissions. However, biofuels are also an option for GHG mitigation, although the use of energy crops implies local impacts derived from cultivation. On the other hand, if local manufacturing of BEVs ever takes place in Brazil, it will be fundamental to control the potential ozone depletion effects linked to aluminum recycling [37].

BEVs disruption reflects a change in technology and paradigms beyond mere transportation. A myriad of new businesses is expected to sprout from the interactions between the vehicles, the electric grid, the EVSE and the users. In order to harness the potential of this new market, highly skilled workers and investments in research and development are necessary. Therefore, if Brazil relinquishes the possibility of investing in $R \& D$, it would squander the opportunity to develop and produce BEV technology. Any negative socioeconomic effects, such as job losses and resigning the leadership in the biofuels field, must be overcome by finding technological routes to integrate electrification and biofuels.

A few steps towards such integration have already been taken. The flex-fuel hybrid vehicle [142] (plug-in or not) is an option which could be explored in the short term, at much more reasonable costs than BEVs, especially in developing countries with the potential for biofuels. However, this technology may unfortunately face difficulties in meeting tailpipe emission restrictions issued by Proconve. Moreover, depending on the guidelines of Rota 2030 program, flex-fuel hybrids could be of limited appeal for automakers. In the long run, the aforementioned SOFC Nissan prototype signals a new technological route to be explored [117]. Also, assuming fuel-cell technologies based on off-board reforming are going to be economically feasible, hydrogen production via a steam reform process from any bio-based feedstock (e.g., bioethanol, biomethane, or even glycerol) could be considered as an option. In addition, if transport electrification via BEVs represents larger fleets in the future, biofuels consumption would be reduced, but biomass could be at least partially shifted to electricity production [143].

Supplementary Materials: The following are available online at http://www.mdpi.com/2032-6653/11/3/60/s1.

Author Contributions: J.E.V.V. and J.E.A.S. were responsible for the conceptualization, information gathering and validation, original draft preparation and writing review, editing and visuals. C.K.N.C., A.C.S.W., S.P.S. and D.G.F. participated in writing review and editing and visuals. J.E.A.S., C.K.N.C. and A.C.S.W. contributed also with funding acquisition and supervision. All authors have read and agreed to the published version of the manuscript.

Funding: The authors would like to thank Conselho Nacional de Desenvolvimento Científico e Tecnológico (CNPq) and Coordenação de Aperfeiçoamento de Pessoal de Nível Superior (CAPES) for the financial support.

Acknowledgments: We would like to thank CPFL Paulista for the partnership and the financial support of this project (PD-00063-3043/2018).

Conflicts of Interest: The authors declare no conflict of interest

\section{References}

1. Mc Kinsey \& Company. The Global Electric-Vehicle Market Is Amped up and on the Rise. Automot Assem. 2018. Available online: https:/www.mckinsey.com/industries/automotive-and-assembly/our-insights/theglobal-electric-vehicle-market-is-amped-up-and-on-the-rise (accessed on 6 December 2018).

2. Erickson, L.E. Reducing Greenhouse gas emissions and improving air quality: Two global challenges. Environ. Prog. Sustain. Energy 2017, 36, 982-988. [CrossRef] [PubMed]

3. Naughton, K.; Welch, D. This Is What Peak Car Looks Like. Bloom Businessweek. Available online: https://www. bloomberg.com/news/features/2019-02-28/this-is-what-peak-car-looks-like (accessed on 16 November 2019).

4. Dinero. Chile Tendrá la Flota de Buses Eléctricos Más Grande de América Latina. Available online: https: //www.dinero.com/internacional/articulo/buses-y-movilidad-electrica-en-chile-es-lider-en-la-region/265627 (accessed on 5 July 2019). 
5. Portafolio. Así Está Avanzando la Movilidad Eléctrica en América Latina. Portafolio. 2018. Available online: https:/www.portafolio.co/economia/asi-esta-avanzando-la-movilidad-electrica-enamerica-latina-524234 (accessed on 9 October 2019).

6. Zaparolli, D. Elétricos no Horizonte. Pesqui Fapesp. Available online: https://revistapesquisa.fapesp.br/ 2019/09/06/eletricos-no-horizonte/ (accessed on 7 November 2019).

7. Consoni, F.L.; Oliveira, A.; Barassa, E.; Martínez, J.; de Carvalho, B.T.M.M. Estudo de Governança e Políticas Públicas para Veículos Elétricos Estudo de Governança e Políticas Públicas para Veículos Elétricos. Available online: https://edisciplinas.usp.br/pluginfile.php/4278022/mod_resource/content/1/PROMOBeEstudodeGovernanca.pdf (accessed on 15 January 2020).

8. Vasconcelos, Y. The Challenges Faced in BRAZIL. Pesqui Fapesp. Available online: http://revistapesquisa. fapesp.br/en/2018/01/12/the-challenges-faced-in-brazil/ (accessed on 1 May 2019).

9. Brasil. Resolução $N^{0}$ 97, de 26 de Outubro de 2015. Secr Da Câmara Comércio Exter. Available online: http://www.camex.gov.br/component/content/article/62-resolucoes-da-camex/em-vigor/ 1564-resolucao-n-97-de-26-de-outubro-de-2015 (accessed on 26 February 2019).

10. Yang, Z.; Slowik, P.; Lutsey, N.; Searle, S. Principles for Effective Electric Vehicle Incentive Design. 2016. Available online: https://www.theicct.org/sites/default/files/publications/ICCT_IZEV-incentives-comp_ 201606.pdf (accessed on 22 December 2019).

11. Sierzchula, W.; Bakker, S.; Maat, K.; Van Wee, B. The Influence of Financial Incentives and Other Socio-Economic Factors on Electric Vehicle Adoption. Energy Policy 2014, 68, 183-194. [CrossRef]

12. Hardman, S.; Chandan, A.; Tal, G.; Turrentine, T. The Effectiveness of Financial Purchase Incentives for Battery Electric Vehicles-A Review of the Evidence. Renew. Sustain. Energy Rev. 2017, 80, 1100-1111. [CrossRef]

13. De Araujo, A.C.; Amorim, R.E. Electric Mobility-The Challenges of Regulating the Charging Infrastructure during Early Market Development in Brazil. Available online: http://mobilityintegrationsymposium. org/wp-content/uploads/sites/7/2017/11/2B_2_EMob17_057_paper_Antonio_Araujo_Ronald_Amorim.pdf (accessed on 9 November 2019).

14. Li, Y. Infrastructure to Facilitate Usage of Electric Vehicles and its Impact. Transp. Res. Procedia 2016, 14, 2537-2543. [CrossRef]

15. Prefeitura de São Paulo. Veículos Elétricos e Híbridos são Isentos do Rodízio Municipal. Available online: http: //www.capital.sp.gov.br/noticia/veiculos-eletricos-e-hibridos-sao-isentos-do (accessed on 26 February 2019).

16. Teixeira, L. O Que Falta Para os Carros Elétricos Invadirem o Brasil. Forbes. 2018. Available online: https: //forbes.uol.com.br/negocios/2018/10/o-que-falta-para-os-carros-eletricos-invadirem-o-brasil/ (accessed on 25 October 2019).

17. Reis, A. Carregador de Carro Elétrico: Quanto Custa Instalar em Casa ou no Trabalho. Available online: https://carros.uol.com.br/noticias/redacao/2018/05/04/carregador-de-carro-eletricoquanto-custa-instalar-em-casa-ou-no-trabalho.htm (accessed on 10 December 2018).

18. Associação Brasileira do Veículo Elétrico. Áreas de Mobilidade Urbana Verde. 2017. Available online: http://www.abve.org.br/muv/ (accessed on 10 December 2018).

19. Laurischkat, K.; Viertelhausen, A.; Jandt, D. Business Models for Electric Mobility. Procedia CIRP 2016, 47, 483-488. [CrossRef]

20. Marchán, E.; Viscidi, L. Green Transportation the Outlook for Electric Vehicles in Latin America. Dial. Can. Philos. Assoc. 2015,1-16. Available online: http://www.thedialogue.org/wp-content/uploads/2015/10/GreenTransportation-The-Outlook-for-Electric-Vehicles-in-Latin-America.pdf (accessed on 6 June 2019).

21. ANFAVEA. Estatísticas. 2019. Available online: http://www.anfavea.com.br/estatisticas-copiar-2.html (accessed on 8 July 2019).

22. European Automobile Manufacturers Association. Top 10: Car Producing Countries, Worldwide and EU. Available online: https://www.acea.be/statistics/article/top-10-car-producing-countries-worldwide-and-eu (accessed on 25 February 2019).

23. International Organization of Motor Vehicle Manufacturers. 2018 Production Statistics. 2019. Available online: http://www.oica.net/category/production-statistics/2018-statistics/ (accessed on 2 February 2020).

24. Brasil. Setor Automotivo. Ministério Da Econ Indústria, Comércio Exter e Serviços. Available online: http: //www.mdic.gov.br/index.php/competitividade-industrial/setor-automotivo (accessed on 8 September 2019). 
25. International Energy Agency. Biofuels for Transport. Tracking Clean Energy Progress. Available online: https://www.iea.org/tcep/transport/biofuels/ (accessed on 25 February 2019).

26. Agência Nacional de Energia Elétrica. Resolução Normativa No 819, de 19 de Junho de 2018. Available online: http://www2.aneel.gov.br/cedoc/ren2018819.pdf (accessed on 10 August 2019).

27. Gallas, D. The Country Built on Trade Barriers. Available online: https://www.bbc.com/news/business44902104 (accessed on 8 June 2018).

28. Brasil. Importação de Automóveis Cresce 48\% Após fim do Inovar Auto. Agência Bras. Available online: http://agenciabrasil.ebc.com.br/economia/noticia/2018-04/importacao-de-automoveiscresce-48-apos-fim-do-inovar-auto (accessed on 6 December 2018).

29. European Commission. Key Elements of the EU-Mercosur Trade Agreement. Press Release Database. Available online: https://europa.eu/rapid/press-release_QANDA-19-3375_en.htm (accessed on 2 July 2019).

30. Sindipeças. Relatório da Frota Circulante. 2019. Available online: https://www.sindipecas.org.br/sindinews/ Economia/2019/RelatorioFrotaCirculante_Maio_2019.pdf (accessed on 3 January 2020).

31. CNPEM. Eletrificação de Veículos e o Futuro do Etanol Combustível no Brasil. Separatas CNPEM. Available online: http://cnpem.br/acesso-a-informacao/separatas-cnpem/ (accessed on 6 August 2019).

32. EPE. The Brazilian Commitment to Combating Climate Change: Energy Production and Use. 2016. Available online: http://www.epe.gov.br/sites-en/publicacoes-dados-abertos/publicacoes/PublicacoesArquivos/ publicacao-181/NTCOP21-English.pdf (accessed on 17 October 2019).

33. Faria, R.; Marques, P.; Moura, P.; Freire, F.; Delgado, J.; de Almeida, A.T. Impact of the electricity mix and use profile in the life-cycle assessment of electric vehicles. Renew. Sustain. Energy Rev. 2013, 24, 271-287. [CrossRef]

34. Boureima, F.S.; Messagie, M.; Matheys, J.; Wynen, V.; Sergeant, N.; van Mierlo, J.; de Vos, M.; de Caevel, B. Comparative LCA of electric, hybrid, LPG and gasoline cars in Belgian context. World Electr. Veh. J. 2009, 3, 1-8. [CrossRef]

35. Hawkins, T.R.; Singh, B.; Majeau-Bettez, G.; Strømman, A.H. Comparative Environmental Life Cycle Assessment of Conventional and Electric Vehicles. J. Ind. Ecol. 2013, 17, 53-64. [CrossRef]

36. Ma, H.; Balthasar, F.; Tait, N.; Riera-Palou, X.; Harrison, A. A new comparison between the life cycle greenhouse gas emissions of battery electric vehicles and internal combustion vehicles. Energy Policy 2012, 44, 160-173. [CrossRef]

37. Velandia, V.J.E.; Falco, D.G.; Walter, A.C.S.; Cavaliero, C.K.N.; Seabra, J.E.A. Life cycle assessment of electric vehicles and buses in Brazil: Effects of local manufacturing, mass reduction, and energy consumption evolution. Int. J. Life Cycle Assess. 2019, 24, 1878-1897. [CrossRef]

38. Choma, E.F.; Ugaya, C.M.L. Environmental impact assessment of increasing electric vehicles in the Brazilian fleet. J. Clean Prod. 2013, 152, 497-507. [CrossRef]

39. Cano, Z.P.; Banham, D.; Ye, S.; Hintennach, A.; Lu, J.; Fowler, M.; Chen, Z. Batteries and fuel cells for emerging electric vehicle markets. Nat. Energy 2018, 3, 279-289. [CrossRef]

40. dos Santos, N.C.; Francischetti, C.E.; da Silva, R.G. Analysis of Electric Vehicles: A Brazillian Reality and Its Consequences for the Environment. Int. Conf. Renew. Energies Power Qual. 2014, 1, 195-200. [CrossRef]

41. Alisson, E. Proálcool: Uma das Maiores Realizações do Brasil Baseadas em Ciência e Tecnologia. Agência Fapesp. Available online: http://agencia.fapesp.br/proalcool-uma-das-maiores-realizacoes-dobrasil-baseadas-em-ciencia-e-tecnologia/24432/ (accessed on 20 April 2019).

42. Cortez, L.A.B.; Nogueira, L.A.H.; Leal, M.R.V.L.; Junior, R.B. 40 Years of the Brazilian Ethanol Program (Proálcool): Relevant Public Policies and Events Throughout Its Trajectory and Future Perspectives. Available online: http://bioenfapesp.org/gsb/lacaf/documents/papers/05_ISAF_2016_Cortez_ et_al.pdf (accessed on 8 March 2020).

43. Silva, C. Veiculos Eletricos Fabricados no Brasil Comecam a Ganhar as Ruas. Estadão. Available online: https://link.estadao.com.br/noticias/inovacao,veiculos-eletricos-fabricados-no-brasilcomecam-a-ganhar-as-ruas,70002948251 (accessed on 16 December 2019).

44. Itaipu Binacional. Veículos Elétricos. Available online: https://www.itaipu.gov.br/tecnologia/veiculoseletricos (accessed on 8 December 2018).

45. Abravei. Associação Brasileira dos Proprietários de Veículos elétricos Inovadores. Available online: http://abravei.org/ (accessed on 10 December 2018). 
46. Fontes, F.A.S. Sistematização de Iniciativas de Mobilidade Elétrica no Brasil. Available online: http: //www.promobe.com.br/library/sistematizacao-de-iniciativas-de-mobilidade-eletrica-no-brasil/ (accessed on 19 March 2019).

47. Mc Kinsey \& Company. Trends in Electric-Vehicle Design. Automot Assem. Available online: https://www. mckinsey.com/industries/automotive-and-assembly/our-insights/trends-in-electric-vehicle-design (accessed on 30 August 2018).

48. Mc Kinsey \& Company. What a Teardown of the Latest Electric Vehicles Reveals about the Future of Mass-Market EVs. Automot Assem. Available online: https://www.mckinsey.com/industries/automotiveand-assembly/our-insights/what-a-teardown-of-the-latest-electric-vehicles-reveals-about-the-future-ofmass-market-evs\#0 (accessed on 4 December 2018).

49. Mc Kinsey \& Company. Making Electric Vehicles Profitable. Automot Assem. Available online: https: //www.mckinsey.com/industries/automotive-and-assembly/our-insights/making-electric-vehicles-profitable (accessed on 10 May 2019).

50. European Automobile Manufacturers Association. Auto Makers Welcome Conclusion of EU-Mercosur Trade Deal. 2019. Available online: https://www.acea.be/press-releases/article/auto-makers-welcome-conclusionof-eu-mercosur-trade-deal (accessed on 11 July 2019).

51. Barassa, E. Trajetória Tecnológica Do Veículo Elétrico: Atores, Políticas E Esforços Tecnológicos No Brasil. Available online: http://repositorio.unicamp.br/jspui/handle/REPOSIP/287784 (accessed on 19 April 2019).

52. Redetic. Sobre o Sibratec. Available online: http://www.redetic.rnp.br/sobre-o-sibratec/ (accessed on 20 April 2019).

53. Lima, M.S.; Pinheiro, M.V.; de Oliveira, J.D.; de Neto, O.C.; Lopes, S.A. Modelos de Negócios Aplicados a Compartilhamento de Veículos Elétricos. XX SEMEAD Semin. Em. Adm. 2017, 1, 1-14. [CrossRef]

54. Teles, F.; Magri, R.T.G.; Ordoñez, R.E.C.; Anholon, R.; Costa, S.L.; Santa-Eulalia, L.A.D. Sustainability measurement of product-service systems: Brazilian case studies about electric car-sharing. Int. J. Sustain. Dev. World Ecol. 2018, 25, 722-729. [CrossRef]

55. Mariotto, F.T. Metodologia para Avaliação dos Impactos Financeiros para as Distribuidoras de Energia Elétrica Brasileiras Resultantes da Inserção de Veículos Elétricos. Available online: http://repositorio.unicamp. br/jspui/bitstream/REPOSIP/332024/1/Mariotto_FlavioTonioli_M.pdf (accessed on 18 November 2019).

56. Pinto, D.R.; Arioli, V.T.; Hax, G.R.T.; Taniguchi, F.K.; Torquato, R.; Teixeira, W.W.; Eduardo, P.L. Field investigation of the power quality impact of electric vehicles in secondary residential systems. In Proceedings of the 18th International Conference on Harmonics and Quality of Power (ICHQP), Ljubljana, Slovenia, 13 May 2018; pp. 1-6. [CrossRef]

57. Arioli, V.T.; Pinto, D.R.; Hax, G.R.T.; Nascimento, T.C.D.; Beck, R.F.; Goiabeira, V.C.P.M.; Teixeira, W.W. Results and Experiences Obtained from the Living Lab of the Electric Mobility Project-A Brazilian Case Study. In Proceedings of the 2017 IEEE Vehicle Power and Propulsion Conference (VPPC), Belfort, France, 11-14 December 2017; pp. 1-6. [CrossRef]

58. Luna, T.F.; Uriona-Maldonado, M.; Silva, M.E.; Vaz, C.R. The influence of e-carsharing schemes on electric vehicle adoption and carbon emissions: An emerging economy study. Transp. Res. Part D 2020, 79, 102226. [CrossRef]

59. Brasil. Congresso Nacional Aprova Incentivos à Indústria Automotiva. Available online: http://www.brasil. gov.br/noticias/economia-e-financas/2018/11/congresso-nacional-aprova-incentivos-a-industria-automotiva (accessed on 6 December 2018).

60. Brasil. Rota 2030 vai Fortalecer e Modernizar a Indústria Automobilística Nacional. Available online: http://www.brasil.gov.br/noticias/economia-e-financas/2018/07/rota-2030-vai-fortalecer-e-modernizar-aindustria-automobilistica-nacional (accessed on 10 December 2018).

61. Bland, D. Brazil's EV Manufacturers Pressured by Energy Efficiency Goals. GlobalfleetCom. Available online: https:/www.globalfleet.com/en/taxation-and-legislation/latin-america/news/brazils-evmanufacturers-pressured-energy-efficiency (accessed on 6 December 2018).

62. Bland, D. Brazil Automakers: ROTA 2030 EV Incentives Weak. GlobalfleetCom. Available online: https://www.globalfleet.com/en/taxation-and-legislation/latin-america/features/brazil-automakers-rota-2030ev-incentives-weak (accessed on 6 December 2018).

63. Brasil. Projeto de Lei do Senado $\mathrm{n}^{\circ}$ 780, de 2015. Atividade Legis. Available online: https://www25.senado. leg.br/web/atividade/materias/-/materia/124442 (accessed on 8 April 2019). 
64. Brasil. Projeto de Lei do Senado $n^{\circ} 454$, de 2017. 2017. Available online: https://www25.senado.leg.br/web/ atividade/materias/-/materia/131656 (accessed on 5 June 2019).

65. Petroff, A. These Countries Want to Ban Gas and Diesel Cars. CNN Bus. Available online: https://money.cnn. com/2017/09/11/autos/countries-banning-diesel-gas-cars/index.html (accessed on 4 May 2019).

66. Agência Nacional de Energia Elétrica. Minuta de edital: Desenvolvimento de Soluções em Mobilidade Elétrica Eficiente. Available online: http://www.aneel.gov.br/consultas-publicas?p_p_id=consultaspublicasvisualizacao_ WAR_AudienciasConsultasPortletportlet\&p_p_lifecycle=2\&p_p_state=normal\&p_p_mode=view\&p_p_ cacheability=cacheLevelPage\&p_p_col_id=column-2\&p_p_col_count=1\&_consultaspublicasvisu (accessed on 3 February 2020).

67. Brasil. Publicados Estudos de Apoio Para Elaboração do Plano Nacional de Energia 2050. Available online: http://www.mme.gov.br/web/guest/pagina-inicial/outras-noticas/-/asset_publisher/32hLrOzMKwWb/ content/publicados-estudos-de-apoio-para-elaboracao-do-plano-nacional-de-energia-2050 (accessed on 9 April 2019).

68. Brasil. MDIC Reúne Especialistas Para Discutir a Eletromobilidade no Brasil. Ministério Da Ind Comércio Exter e Serviços. Available online: http://www.mdic.gov.br/index.php/noticias/3364-mdic-reune-especialistas-paradiscutir-a-eletromobilidade-no-brasil (accessed on 12 December 2018).

69. Empresa de Pesquisa Energética. Eletromobilidade e Biocombustíveis. Documento de Apoio ao PEN 2050. Available online: https://www.google.com.hk/url?sa=t\&rct=j\&q=\&esrc=s\&source=web\&cd= \&ved=2ahUKEwiJrqb1t9vrAhUrxYsBHSBVAIIQFjAAegQIBRAB\&url=http\%3A\%2F\%2Fwww.mme. gov.br\%2Fdocuments $\% 2 F 36208 \% 2 F 478430 \% 2 F 17 . \% 2 B E l e t r o m o b i l i d a d e \% 2 B e \% 2 B B i o c o m b u s t ~ \% 25 C 3 \%$ 25ADveis.pdf\%2F4116e9df-6ab1-f714-5787-3f087fbc47bf\%3Fversion\%3D1.0\%26download\%3Dtrue\& usg=AOvVaw2xS5Lzt5R6DtnMtWgCXDtv (accessed on 21 October 2019).

70. Zhao, H.; Li, N. Optimal Siting of Charging Stations for Electric Vehicles Based on Fuzzy Delphi and Hybrid Multi-Criteria Decision Making Approaches from an Extended Sustainability Perspective. Energies 2016, 9, 270. [CrossRef]

71. Wood, E.; Rames, C.; Muratori, M.; Raghavan, S.; Young, S. Charging Electric Vehicles in Smart Cities: An EVI-Pro Analysis of Columbus, Ohio 2018. Available online: http://www.osti.gov/biblio/1421381-chargingelectric-vehicles-smart-cities-evi-pro-analysis-columbus-ohio (accessed on 9 August 2019).

72. Calçado, T.E.d.O. Estudo Preliminar De Implantação De Estações De Recarga De Veículos Elétricos No Centro De Tecnologia Da Ufrj. Ph.D. Thesis, Universidade Federal do Rio de Janeiro, Rio de Janeiro, Brazil, March 2015. Available online: http://www.monografias.poli.ufrj.br/monografias/monopoli10014214.pdf (accessed on 9 June 2019).

73. Peres, L.A.P.; Pessanha, J.F.M.; Serra, J.V.; Particelli, F.M.F.; Caldas, A.C.I. Infrastructure Plan for Charging Stations for Electric Vehicles in Rio de Janeiro. In Proceedings of the EVS26 International Battery, Hybrid and Fuel Cell Electric Vehicle Symposium, Los Angeles, CA, USA, 6-9 May 2012; Available online: http://events.ntpshow.com/evs26/public/enter.aspx (accessed on 4 November 2018). [CrossRef]

74. Costa, E.; Paiva, A.; Seixas, J.; Baptista, P.; Costa, G.; Gallachoir, O.B. Suitable Locations for Electric Vehicles Charging Infrastructure in Rio de Janeiro, Brazil. In Proceedings of the 2017 IEEE Vehicle Power and Propulsion Conference (VPPC), Belfort, France, 11-14 December 2017. [CrossRef]

75. Costa, E.; Paiva, A.; Seixas, J.; Baptista, P.; Costa, G.; Gallachoir, O.B. The Best Locations for Charging Infrastructure of Electric Vehicles in Belo Horizonte, Brazil. In Proceedings of the Irish Transport Research Network (ITRN_2017), Dublin, Ireland, 28-29 August 2017; Available online: https://www.researchgate.net/publication/319423114_ The_best_locations_for_charging_infrastructure_of_electric_vehicles_in_Belo_Horizonte_Brazil (accessed on 13 November 2018).

76. Haustein, S.; Jensen, A.F. Factors of electric vehicle adoption: A comparison of conventional and electric car users based on an extended theory of planned behavior. Int. J. Sustain. Transp. 2018, 12, 484-496. [CrossRef]

77. Félix, L. Ir de São Paulo ao Rio Sem Gastar com Combustível já é Possível; Saiba Como. UOL. Available online: https://carros.uol.com.br/noticias/redacao/2018/07/18/ir-de-sao-paulo-ao-rio-sem-gastarcombustivel-ja-e-possivel.htm (accessed on 11 December 2018).

78. Olmos, M. BMW e EDP Investirão em Startups na Área de Mobilidade Elétrica. Valor. Available online: https://www.valor.com.br/empresas/5669163/bmw-e-edp-investirao-em-startups-naarea-de-mobilidade-eletrica (accessed on 11 December 2018). 
79. Massa News. Paraná Inaugura Primeira Eletrovia do País. Available online: https://massanews.com/noticias/ plantao/parana-inaugura-primeira-eletrovia-do-pais-D8YPe.html (accessed on 11 December 2018).

80. Ambiente Energia. Itaipu e Copel Inauguram Estação de Recarga da Primeira Eletrovia do Paraná. Km Ambient. Available online: https:/www.ambienteenergia.com.br/index.php/2018/09/itaipu-e-copel-inauguram-estacaode-recarga-da-primeira-eletrovia-parana/34630\#.XBALG-JrxPZ (accessed on 11 December 2018).

81. Slowik, P.; Araujo, C.; Dallmann, T.; Façanha, C. International Evaluation of Public Policies for Electromobility in Urban Fleets. Available online: http://www.promobe.com.br/library/international-evaluation-of-publicpolicies-for-electromobility-in-urban-fleets/ (accessed on 26 October 2019).

82. Valor. BNDES Aprova R\$ 6,7 mi Para Projetos de Recarga de Veículos Elétricos. Valor Econômico. Available online: https://www.valor.com.br/financas/5929831/bndes-aprova-r-67-mi-para-projetos-derecarga-de-veiculos-eletricos (accessed on 7 December 2018).

83. Embrapii. Projeto EMBRAPII Desenvolve Postos de Abastecimento Para Veículos Elétricos com Tecnologia 100\% Nacional. Available online: http://embrapii.org.br/projeto-embrapii-desenvolve-postos-de-abastecimentopara-veiculos-eletricos-com-tecnologia-100-nacional/ (accessed on 1 May 2019).

84. ABB. ABB Fornece Primeiro Carregador de Veículos Universal Para 1. ${ }^{\circ}$ Eletroposto em Rodovia no Brasil. Available online: http://www.abb.com.br/cawp/seitp202/191f9b8dd0c7883583257f1b0044317c.aspx (accessed on 4 April 2019).

85. BYD. Charging Service. Available online: http://www.byd.ind.br/produtos/charging-service/ (accessed on 2 March 2019).

86. Volvo Brasil. Plug-in Hybrids. Available online: https://www.volvocars.com/br/porque-volvo/inovacaohumana/futuro-da-conducao/propulsao/plug-in-hybrids (accessed on 1 May 2019).

87. Klapwijk, P. EV Related Protocols. Available online: https://www.elaad.nl/uploads/files/EV_related_protocol_ study_v1.1.pdf (accessed on 4 May 2019).

88. EV Connect. OCPP Information. 2018. Available online: https://www.evconnect.com/ocpp/\#steps (accessed on 22 April 2019).

89. Greenlots. Open vs. Closed Charging Stations: Advantages and Disadvantages. Available online: https:/ greenlots.com/wp-content/uploads/2018/09/Open-Standards-White-Paper.pdf (accessed on 17 September 2019).

90. Eurelectric. Deploying Publicly Accessible Charging Infrastructure for Electric Vehicles: How to Organise the Market? 2013. Available online: https://www.eurelectric.org/media/1816/0702_emobility_market_model_ final_ac-2013-030-0501-01-e.pdf (accessed on 1 March 2019).

91. Pratiwi, L. Barriers and Strategies for Transition to Electric Vehicles in BRICS Countries: Case Study of South Africa, India, and Brazil. 2016, pp. 59-66. Available online: https://repository.tudelft.nl/islandora/object/ uuid\%3A0b25e361-31ec-4cbf-9653-1e8764ce1864 (accessed on 12 September 2019).

92. OECD. Brazil-Economic Forecast Summary. Available online: https://www.oecd.org/brazil/brazil-economicforecast-summary.htm (accessed on 9 April 2019).

93. Lim, M.K.; Mak, H.; Rong, Y. Toward Mass Adoption of Electric Vehicles: Impacts of the Range and Resale Anxieties. SSRN Electron. J. 2013, 17, 101-119. [CrossRef]

94. Bermúdez, T. Transições Sócio-Tecnicas Para Uma Mobilidade de Baixo CARBONO: Uma Análise do Nicho dos Ônibus de Baixa Emissão Para o Caso do Brasil. Available online: http://www.repositorio.unicamp.br/ handle/REPOSIP/333639 (accessed on 17 May 2019).

95. Steitz, C. Plug Wars: The Battle for Electric car Supremacy. Reuters. Available online: https://www.reuters.com/ article/us-autos-electricity-charging/plug-wars-the-battle-for-electric-car-supremacy-idUSKBN1FD0QM (accessed on 28 April 2019).

96. Marques, M.d.C.; Mariotto, F.T.; Pinto, D.R.; Consoni, F.L.; Oliveira, M.d.S.G. Cenários de Custo Total de Propriedade de Veículos Elétricos de Frotas Corporativas. In Proceedings of the 24th $24^{\circ}$ Congresso e Mostra Internacionais SAE Brasil de Tecnologia da Mobilidade, São Paulo, Brazil, 22-24 September 2015; pp. 1-10. Available online: http://www.saebrasil.org.br/eventos/congresso2015/Proposta_Patrocinio_2015-1. pdf (accessed on 6 September 2019).

97. Marques, M.d.C.; Silva, É; Consoni, F.L.; Mariotto, F.T. Electric Vehicles Total Cost of Ownership and Public Health Issues in Brazil. Gerpisa Colloq. 2016, 24, 1-16. Available online: http://gerpisa.org/node/3357 (accessed on 16 December 2018). 
98. CPFL Energia. São Paulo Aprova Redução de IPVA Para Carros Eletricos e Hibridos. Available online: https://www.cpfl.com.br/sites/mobilidade-eletrica/mobilidade-e/legislacao/Paginas/SaoPaulo-aprova-reducao-de-IPVA-para-carros-eletricos-e-hibridos.aspx (accessed on 6 July 2019).

99. Goldie-Scot, L. A Behind the Scenes Take on Lithium-ion Battery Prices. Bloomberg. Available online: https://about.bnef.com/blog/behind-scenes-take-lithium-ion-battery-prices/ (accessed on 18 October 2019).

100. Lutsey, N.; Nicholas, M. Update on electric vehicle costs in the United States through 2030. Int. Counc. Clean Transp. 2019, 1-12. [CrossRef]

101. Soltani-Sobh, A.; Heaslip, K.; Bosworth, R.; Barnes, R.; Yook, D. Investigating factors affecting electric vehicles adoption: An aggregated panel data analysis over U.S. states. World Electr. Veh. J. 2015, 7, 681-691. [CrossRef]

102. Brasil. Bandeiras Tarifárias. Available online: http://www.aneel.gov.br/bandeiras-tarifarias (accessed on 4 April 2019).

103. De Azevedo, S.C.; Cardim, G.P.; Puga, F.; Singh, R.P.; Da Silva, E.A. Analysis of the 2012-2016 drought in the northeast Brazil and its impacts on the Sobradinho water reservoir. Remote Sens. Lett. 2018, 9, 438-446. [CrossRef]

104. Petrobras. Gasoline-Composition of Consumer Prices. Available online: http://www.petrobras.com.br/en/ products-and-services/composition-of-sales-prices-to-the-consumer/gasoline/ (accessed on 24 April 2019).

105. Escobar, H. Scientists, Environmentalists Brace for Brazil's Right Turn. Science 2018, 362, 273-274. [CrossRef] [PubMed]

106. Ramos, S.C. Unica Critica IPI Menor Para Carro Elétrico. Valor Econômico. Available online: https://www.valor. com.br/agro/5308289/unica-critica-ipi-menor-para-carro-eletrico (accessed on 10 December 2018).

107. Brasil. Entra em Produção a Plataforma CBIO ANP/SERPRO. 2020. Available online: http://www.anp.gov.br/ noticias/5582-entra-em-producao-a-plataforma-cbio-anp-serpro (accessed on 2 January 2020).

108. Brasil. Pretendida Contribuição Nacionalmente Determinada. 2015. Available online: http://www.itamaraty. gov.br/images/ed_desenvsust/BRASIL-iNDC-portugues.pdf (accessed on 29 December 2019).

109. Alencastro, C. Governo Acaba Com Secretaria Dedicada a Mudanças Climáticas e Gera Temor Entre Cientistas. O Globo. Available online: https:/oglobo.globo.com/sociedade/sustentabilidade/governo-acaba-com-secretariadedicada-mudancas-climaticas-gera-temor-entre-cientistas-23352452 (accessed on 10 February 2020).

110. Moraes, F.T. Inistério do Meio Ambiente vai Enxugar Área de Mudanças Climáticas. Folha. Available online: https://www1.folha.uol.com.br/ambiente/2019/01/ministerio-do-meio-ambiente-vaienxugar-area-de-mudancas-climaticas.shtml (accessed on 6 January 2020).

111. Baran, R.; Legey, L.F.L. The introduction of electric vehicles in Brazil: Impacts on oil and electricity consumption. Technol. Forecast. Soc. Chang. 2013, 80, 907-917. [CrossRef]

112. Vedana, J.C. Etanol e Gasolina Ganharão um Novo Concorrente no Mercado, a Energia Elétrica. NovacanaCom. Available online: https://www.novacana.com/n/combate/carro-eletrico/etanol-gasolina-novo-concorrentemercado-energia-eletrica-020419 (accessed on 1 March 2019).

113. Kane, M. Electric Car Sales in UK Doubled in January 2019: PHEVs Disappoint. Insid EVs. 2019. Available online: https://insideevs.com/all-electric-car-sales-uk-phevs/ (accessed on 5 April 2019).

114. Gillespie, E. GM Pulls the Plug on the Chevrolet Volt, Discontinuing It and These 5 Other Car Models. Fortune. 2018. Available online: http://fortune.com/2018/11/26/gm-discontinue-car-models-chevrolet-voltcruze-impala-buick-lacrosse-cadillac-xts-ct6/ (accessed on 4 April 2019).

115. Adner, R.; Kapoor, R. Right Tech, Wrong Time. Harv. Bus. Rev. 2016, 94, 60-67. Available online: https://hbr.org/2016/11/right-tech-wrong-time (accessed on 6 June 2019). [CrossRef]

116. Carney, D. Mazda's New Skyactiv-X Engine Gives New Life to Internal Combustion. IEEE Spectr. 2018. Available online: https://spectrum.ieee.org/transportation/efficiency/mazdas-new-skyactivx-engine-givesnew-life-to-internal-combustion (accessed on 12 December 2018).

117. Sugimoto, L. Unicamp, Nissan e o Carro Movido Com Eletricidade Gerada por Etanol. Unicamp. Available online: https://www.unicamp.br/unicamp/noticias/2019/04/26/unicamp-nissan-e-o-carro-movido-com-eletricidadegerada-por-etanol?fbclid=IwAR3zxTsXEf5TqDYbmRDRyiMLcS6q0NQ1Te-HdTMcJHMEa0dCBXTqU81c_24 (accessed on 26 April 2019).

118. Silva, C. BYD Inicia Produção de Baterias Para Veículos Elétricos. Estadão. Available online: https://economia. estadao.com.br/noticias/geral,byd-inicia-producao-de-baterias-para-veiculos-eletricos,70003411243 (accessed on 30 August 2020). 
119. Dallmann, T. Climate and Air Pollutant Emissions Benefits of Bus Technology Options in São Paulo. Available online: http://www.promobe.com.br/library/climate-and-air-pollutant-emissions-benefits-of-bustechnology-options-in-sao-paulo/ (accessed on 6 January 2020).

120. O'Donovan, A.; Frith, J.; McKerrach, C. Electric Buses in Cities: Driving Towards Cleaner Air and Lower $\mathrm{CO}_{2}$. 2018. Available online: https://data.bloomberglp.com/professional/sites/24/2018/05/Electric-Buses-inCities-Report-BNEF-C40-Citi.pdf (accessed on 21 November 2019).

121. Glensor, K.; Muñoz, M.R. Life-Cycle Assessment of Brazilian Transport Biofuel and Electrification Pathways. Sustainability 2019, 11, 6332. [CrossRef]

122. Lafranque, A. A Emergência de Modelos de Negocios Inovadores Para Apoiar o Desenvolvimento da Eletrificação Veícular. Available online: http://gesel.ie.ufrj.br/app/webroot/files/publications/04_Lafranque. pdf (accessed on 18 April 2019).

123. Rockmann, R. Incertezas Rondam os Veículos Elétricos. Valor Econômico. Available online: https://www.valor. com.br/brasil/6006413/incertezas-rondam-os-veiculos-eletricos (accessed on 16 December 2018).

124. Haddadian, G.; Khodayar, M.; Shahidehpour, M. Accelerating the Global Adoption of Electric Vehicles: Barriers and Drivers. Electr. J. 2015, 28, 53-68. [CrossRef]

125. Dombrowski, U.; Engel, C. Impact of Electric Mobility on the after Sales Service in the Automotive Industry. Procedia CIRP 2014, 16, 152-157. [CrossRef]

126. Weiller, C.; Neely, A. Using electric vehicles for energy services: Industry perspectives. Energy 2014, 77, 194-200. [CrossRef]

127. Vance, A. Why Elon Musk Just Opened Tesla's Patents to His Biggest Rivals. Bloomberg. Available online: https://www.bloomberg.com/news/articles/2019-04-01/aramco-s-big-reveal-what-welearned-about-the-saudi-oil-giant (accessed on 6 December 2018).

128. Marques, F.L.d.R.; Santos, S.R.d.; Junior, M.F.B.; Nascimento, T.C.d.; Beck, R.F.; Rosolem, M.D.; Figueiredo, R.S.; Pereira, R.V. Advanced Management System for Lithium-ion Batteries in Hybrid Inverters Optimized for Photovoltaic Systems Connected to the Grid. SAE Tech. Pap. Ser. 2017. [CrossRef]

129. Aranha, J.C.M.S.; dos Santos, S.R.; Fracarolli, J.P.V.; Oliveira, E.M., Jr.; Cerri, F. Comparing techniques used to estimate the state of charge of lithium-ion batteries for electric vehicles. SAE Tech. Pap. Ser. 2018, 1, 1-6. [CrossRef]

130. Rocha, S.; Aranha, J.C.M.S.; Chiachio, T.; Vieira, D.; Junior, E.M.O.; Cerri, F. Study of Machine Learning Algorithms to State of Health Estimation of Iron Phosphate Lithium-Ion Battery used in Fully Electric Vehicles. 2018 SAE Bras. Congr. Exhib. 2018, 6-11. [CrossRef]

131. Vaz, L.F.H.; Barros, D.C.; de Castro, B.H.R. Veículos híbridos e elétricos: Sugestões de políticas públicas para o segmento. BNDES Setorial 2015, 41, 295-344. Available online: https://web.bndes.gov.br/bib/jspui/bitstream/ 1408/4284/1/BS\%2041_Ve\%c3\%adculos\%20h\%c3\%adbridos\%20e\%20el\%c3\%a9tricos_P.pdf (accessed on 18 March 2019).

132. Jussani, A.C.; Wright, J.T.C.; Ibusuki, U. Battery global value chain and its technological challenges for electric vehicle mobility. RAI Rev. Adm. Inov. 2017, 14, 333-338. [CrossRef]

133. Träger, T.; Friedrich, B.; Weyhe, R. Recovery Concept of Value Metals from Automotive Lithium-Ion Batteries. Chem. Ing. Tech. 2015, 87, 1550-1557. [CrossRef]

134. Lombrana, L. Lithium Industry Buildup Is Outracing the Electric-Car Boom. Bloomberg. Available online: https://www.bloomberg.com/news/articles/2019-07-28/the-lithium-mine-buildup-is-outpacing-the-electriccar-boom (accessed on 10 November 2019).

135. Lombrana, L. Lithium Battery Dreams Get a Rude Awakening in South America. Bloomberg. Available online: https:/www.bloomberg.com/news/articles/2019-10-11/lithium-battery-dreams-geta-rude-awakening-in-south-america (accessed on 8 June 2019).

136. Biesheuvel, T.; Burton, M. Glencore Halts Cobalt Mine after Lowest Profit in 3 Years. Bloomberg. Available online: https:/www.bloomberg.com/news/articles/2019-08-07/glencore-profits-tumble-in-firsthalf-as-cobalt-prices-collapse (accessed on 26 November 2019).

137. Burton, M.; Biesheuvel, T. Miners Find out the Hard Way Why Cobalt Is Called the Goblin. Bloomberg. Available online: https://www.bloomberg.com/news/articles/2019-08-07/miners-find-out-the-hard-waywhy-cobalt-is-called-the-goblin (accessed on 5 June 2019).

138. Grassi, M.C.B.; Pereira, G.A.G. Energy-cane and RenovaBio: Brazilian vectors to boost the development of Biofuels. Ind. Crops Prod. 2019, 129, 201-205. [CrossRef] 
139. Brasil. RenovaBio. Agência Nac Petróleo, Gás Nat e Biocombustíveis. Available online: http://www.anp.gov. br/biocombustiveis/renovabio (accessed on 27 March 2019).

140. Brasil. Resolução No 492, de 20 de Dezembro de 2018. Diário of Da União. Available online: http://www.in.gov. br/materia/-/asset_publisher/Kujrw0TZC2Mb/content/id/56643907 (accessed on 16 December 2019).

141. de Souza, L.L.P.; Lora, E.E.S.; Palacio, J.C.E.; Rocha, M.H.; Renó, M.L.G.; Venturini, O.J. Comparative environmental life cycle assessment of conventional vehicles with different fuel options, plug-in hybrid and electric vehicles for a sustainable transportation system in Brazil. J. Clean Prod. 2018, 203, 444-468. [CrossRef]

142. Toyota. Hybrid Flex. 2019. Available online: https://www.toyota.com.br/mundo-toyota/sustentabilidade/en/ hibrido-flex (accessed on 1 September 2020).

143. Dranka, G.; Ferreira, P. Electric Vehicles and Biofuels Synergies in the Brazilian Energy System. Energies 2020, 13, 4423. [CrossRef]

(C) 2020 by the authors. Licensee MDPI, Basel, Switzerland. This article is an open access article distributed under the terms and conditions of the Creative Commons Attribution (CC BY) license (http://creativecommons.org/licenses/by/4.0/). 